\title{
ADİ ORTAKLIKTA ORTAĞIN ÖLÜMÜ HALINDE MİRASÇILARIN HUKUKİ DURUMU
}

\author{
Numan TEKELIOOĞLU*
}

\section{$\ddot{O} Z$}

Adi ortaklık, ekonomik ve hukuki anlamda oldukça önemli fonksiyonlara sahip bir ortaklı türüdür. Ortakların kişisel özelliklerinin ön planda olduğu adi ortaklıkta, ortaklardan birinin ölümü muhtelif sorunların gün yüzüne çıkmasına sebep olabilmektedir. Bu sorunların temelinde, ortağın ölümünün adi ortaklı̆̆ sona erdirip erdirmeyeceği ve buna bağlı olarak mirasçıların adi ortaklıkla ilişkilerinin nasıl olacağı meselesi yer almaktadır. Ortağın ölümüyle birlikte adi ortaklı̆̆ın sona erdiği hallerde durum daha basittir. Ortakllk tasfiye sürecine girer ve tasfiye sonucunda elde edilen kar veya zarara mirasçılar da katlanır. Ancak adi ortaklı̆̆ın mirasçılarla sürdürülmesi söz konusu olduğunda, miras ortaklı̆̆ına hâkim olan elbirliği ilkesinin adi ortaklık bakımından elverişli olup olmadığı konusu gündeme gelmektedir. Bunun dışında, ortaklı̆̆ın să̆ kalan ortaklarla sürdürülmesine yönelik sözleşme kayıtları da bulunabilir. Tüm bu hallerde, mirasçıların diğer ortaklara ve birbirlerine karşı hukuken nasıl bir konumda bulunacakları üzerinde durmak gerekmektedir.

Anahtar Kelimeler: Adi Ortaklık, Mirasçı, Miras Ortaklı̆̆l, Halefiyet, Elbirliği Mülkiyeti.

\section{LEGAL STATUS OF HEIRS IN THE EVENT OF THE DEATH OF THE PARTNER IN THE SIMPLE PARTNERSHIP}

\section{ABSTRACT}

Simple partnership is a type of partnership that has very important economic and legal functions. In the simple partnership, where the personal characteristics of the partners are at the forefront, the death of one of the partners may cause various problems to come to light. The basis of these problems is whether the death of the partner will end the simple partnership and, accordingly, how the relations of the heirs with the simple partnership will be. The situation is simpler where the simple partnership ends with the death of the partner. The partnership enters the liquidation

* Arş. Gör. Dr, Süleyman Demirel Üniversitesi Hukuk Fakültesi Medeni Hukuk Anabilim Dal1/ISPARTA e-posta: numantekelioglu@gmail.com

ORCID: 0000-0001-5787-4137

DOI : 10.34246/ahbvuhfd.979233

Yayın Kuruluna Ulaştığı Tarih :28 04//2021

Yayınlanmasının Uygun Görüldüğü Tarih: 30/07/2021 
process and the heirs bear the profit or loss obtained as a result of the liquidation. However, when it comes to the continuation of the simple partnership with the heirs, the issue of whether the principle of cooperation that prevails in the inheritance partnership is suitable for simple partnership comes to the agenda. Apart from this, there may also be contract rules for the continuation of the partnership with the surviving partners. In all these cases, it is necessary to focus on the legal position of the heirs to other partners and to each other.

Keywords: Simple Partnership, Heir, Community of Heirs, Subrogation, Joint Ownership.

\section{GİRIŞ}

Adi ortakl1k (einfache Gesellschaft), emeklerini veya araçlarını ortak bir amaç doğrultusunda bir araya getirerek bu amaca ulaşmak için birlikte çaba göstermeyi sözleşmeye dayalı olarak birbirlerine karşı yüklenen kişiler tarafından meydana getirilen ve tüzel kişiliğe sahip olmayan kişi ortaklığı şeklinde tanımlanmaktadır ${ }^{1}$. Söz konusu tanımdan da anlaşıldığ1 gibi, ortaklık türleri için yapılan klasik ayrımda adi ortaklık, kişi ortaklıkları (Personengesellschaften) içerisinde sayılmaktadır ${ }^{2}$. Zira adi ortaklıkta ortakların kişisel özellikleri, bir anlamda ortaklığı meydana getiren en önemli sebepler arasındadır. Diğer bir deyişle, adi ortaklığın oluşumu bakımından en temel unsurlardan biri, kişi unsurudur ${ }^{3}$.

1 Muhtelif tanımlar için bkz: Nami Barlas, Adi Ortaklık Temeline Dayalı Sözleşme İlişkileri, 4. Bası, Vedat Kitapçılık, İstanbul, 2016, s. 12 vd; Hayri Domaniç, Türk Ticaret Kanunu Şerhi, Cilt I, İstanbul, 1988, s. 377; Lukas Handschin/Reto Vonzun, ZK - Zürcher Kommentar Band/Nr. V/4a, Kommentar zum schweizerischen Zivilrecht, Obligationenrecht, 4. Teil: Die Personengesellschaften, 4. Auflage, Schulthess Juristische Medien AG, 2009, Art. 530, N. 2; Christof Truniger, Präjudizienbuch OR, 9. Auflage, Schulthess Juristische Medien AG, 2016, Art. 530, N. 1; Walter Fellmann/Karin Müller, BK - Berner Kommentar Band/Nr. VI/2/8, Schweizerisches Zivilgesetzbuch, Das Obligationenrecht, Die einzelnen Vertragsverhältnisse, Stämpfli Verlag AG, 2006, Art. 530, N. 11; Jürg G. Schütz, SHK Stämpflis Handkommentar, Personengesellschaftsrecht (Art. 530-619 OR), Stämpfli Verlag AG, 2015, Art. 530, N. 1.

2 Barlas, s. 8; Fikret Eren, Borçlar Hukuku Özel Hükümler, 5. Bası, Yetkin Yayınları, Ankara, 2017, s. 830; Handschin/Vonzun, ZK-OR, Art. 530, N. 1; Fellmann/Müller, BKOR, Art. 530, N. 22; Peter Jung, CHK - Handkommentar zum Schweizer Privatrecht, Personengesellschaften und Aktiengesellschaft -Vergütungsverordnung, 3. Auflage, Schulthess Juristische Medien AG, 2016, Art. 530, N. 3.

3 Truniger, Präjudizienbuch OR, Art. 530, N. 3; Fellmann/Müller, BK-OR, Art. 530, N. 11; 
Türk Borçlar Kanunu m. 620/1 hükmünde adi ortaklık sözleşmesinin tanımı verilmiş ve burada “... iki ya da daha fazla kişinin...” denilmek suretiyle, kişi türleri bakımından bir sınırlamaya gidilmemiştir. Bu sebeple, adi ortaklıkta hem gerçek hem de tüzel kişiler ortak sıfatıyla yer alabilmektedir ${ }^{4}$. Hal böyle olmakla birlikte, ortağın ölümü ve buna bağlı olarak mirasçıların diğer ortak ya da ortaklarla ilişkilerinden bahsedebilmek için, doğal olarak gerçek kişi ortağın bulunması gerekmektedir. Gerçek kişi ortağın ölümü, kural olarak adi ortaklığın sona ermesine yol açan bir sebeptir. Bu ihtimalde, ölen ortağın mirasçılarının diğer ortak veya ortaklarla olan ilişkisi, ortaklığın tasfiyesine dayalı bir alacak ve borç ilişkisidir ${ }^{5}$. Ortağın ölümünün adi ortaklığı sona erdirmediği durumlarda ise, mirasçıların ne şekilde ortaklığa dâhil olacakları meselesiyle karşılaşılmaktadır. Ölen ortağın tek mirasçısının var olması halinde herhangi bir sorun yoktur. Ancak olayların çoğunluğunda ölen ortağın birden fazla mirasçısı bulunur ve bu durum, mirasçıların adi ortaklıkla olan ilişkilerinin karmaşı hale gelmesine yol açar. Zira meselenin merkezinde bir taraftan adi ortaklık varken, diğer taraftan da mirasçıların kendi aralarında kanun gereği meydana gelen miras ortaklığı bulunmaktadır.

\section{ORTAĞIN ÖLÜMÜNÜN ADİ ORTAKLIĞA ETKİSi}

Adi ortaklığın karşılıklı güven ilişkisine ve kişiye bağlı yapısı, ortağın ölümü halinde kendisini açıkça göstermektedir ${ }^{6}$. Nitekim kanunda, ortaklardan birinin ölmesiyle adi ortaklığın sona ereceği düzenlenmiştir (TBK m. 639, b.2/OR Art. 545, Abs. 1, Ziff. 2). Ancak adi ortaklık sözleşmesinde ortaklığın mirasçılarla sürdürülmesi konusunda bir hüküm bulunduğu takdirde, ortağın

Jung, CHK-OR, Art. 530, N. 3; Schütz, SHK- OR, Art. 530, N. 4; Handschin/Vonzun, ZKOR, Art. 530, N. 7.

4 Eren, Özel Hükümler, s. 831; Barlas, s. 19; Fellmann/Müller, BK-OR, Art. 530, N. 19; Truniger, Präjudizienbuch OR, Art. 530, N. 3; Handschin/Vonzun, ZK-OR, Art. 530, N. 2; Schütz, SHK- OR, Art. 530, N. 6; Jung, CHK-OR, Art. 530, N. 3; Karin Müller, OFK - Orell Füssli Kommentar, Schweizerisches Obligationenrecht, 3. Auflage, Orell Füssli Verlag AG, 2016, Art. 530, N. 4.

5 "Ortaklardan birinin ölümü halinde mirasçılar ile şirketin devamına ilişkin ortaklar arasında bir sözleşme olmadiğı da uyuşmazlık konusu değildir. Bu durumda Borçlar Kanunu `nun 535. maddesi uyarınca adi ortaklık sona ermiştir ve davacılar ancak ortaklığın tasfiyesini ve bunun sonucundan doğan alacaklarını isteyebilirler. Oysa davacılar kar isteklerini saklı tutmak suretiyle sadece mirasbırakanlarının koyduğu sermayeyi istemişlerdir. Az önce belirtilen nedenle böyle bir davanın dinlenmesi olanağl yoktur”. Yarg. 13. HD, E. 1974/1156, K. 1974/268, T. 4.2.1974.

6 Emre Türkmen, Adi Ortaklıkta Çıkma ve Çıkarılma, 1. Baskı, Seçkin Yayınları, Ankara, 2020, s. 136. 
ölümü kendiliğinden ortaklığın sona ermesi sonucunu doğurmayacaktır

Ortağın ölümünün adi ortaklığı sona erdirdiği hallerde, ölen ortağın ortaklık sıfatı ve buna bağlı olarak sahip olduğu ortaklık hakları mirasçılara intikal etmez ${ }^{8}$. Öte yandan, adi ortaklığın sona ermesiyle birlikte ortaklığın amacı değişmektedir ${ }^{9}$. Bundan sonraki aşamada ortaklık, alacakların tahsili, borçların ödenmesi ve geriye aktif bir değer kalırsa bunun ortaklar arasında paylaştırılması amacıyla varlığını sürdürür. Tasfiye amacı (Liquidationszweck) olarak adlandırılan bu süreç neticesinde, kanunun ifadesiyle geriye kalan kazanç (TBK m. 643/1) miktarı bakımından ölen ortağın mirasçıları alacaklı konumundadır. Başka bir ifadeyle, ölen ortağın tasfiye sonucunda elde edecek olduğu miktar, onun terekesinin aktif kısmında yer alarak mirasçılara geçmektedir. Bunun dışında, TBK m. 643/1 hükmü çerçevesinde tasfiye süreci içerisinde ödenmesi gereken başka değerler de bulunmaktadır. Tasfiye sonucunda ortaklığın varlığının ortakların katılım paylarını ödemeye yetmemesi veya borçların ödenememesi de söz konusu olabilir. Mirasçılar bu ihtimalde diğer ortak veya ortaklar gibi zarara katılmak ve borçlar bakımından da müteselsilen sorumlu olmak durumundadır.

Adi ortaklık sözleşmesinde, ortaklardan birinin ölümü halinde ortaklığın mirasçılarla devam edeceği yönünde bir hüküm varsa, ölen ortağın ortaklık sıfatı mirasçılara geçer. Böylece, adi ortaklık ölüm olayından etkilenmeyerek varlığını devam ettirme imkânı bulur. Ancak adi ortaklık sözleşmesinde, ortaklığın sağ kalan ortakların kendi aralarında devam edeceği şeklinde

7 Türkmen, s. 136; Cevdet Yavuz/Faruk Acar/Burak Özen, Türk Borçlar Hukuku Özel Hükümler, Beta, 10. Bas1, İstanbul, 2014, s. 1525; Truniger, Präjudizienbuch OR, Art.545, N. 4; Jung, CHK-OR, Art. 545, N. 4; Müller, OFK-OR, Art. 545, N. 4; Handschin/ Vonzun, ZK-OR, Art. 545, N. 35; Benedict F. Christ, SHK - Stämpflis Handkommentar, Personengesellschaftsrecht (Art. 530-619 OR), Stämpfli Verlag AG, 2015, Art. 545, N. 13; Stephan Wolf, "Erb- und (immobiliar)sachenrechtliche Aspekte der einfachen Gesellschaft, insbesondere im Zusammenhang mit personellen Wechseln im Bestand der Gesellschafter", Güter- und erbrechtliche Fragen zur einfachen Gesellschaft und zum bäuerlichen Bodenrecht, Stämpfli Verlag AG, 2005, s. 80; Lukas Handschin, "Die Auflösung der einfachen Gesellschaft", Gesellschafts- und Kapitalmarktrecht in Deutschland, Österreich und der Schweiz, Mohr Siebeck, Tübingen, 2014, s. 219. Peter Jung, "Die Regelung der Nachfolge beim Tod eines Personengesellschafters - Zum notwendigen Zusammenspiel von Erbrecht und Gesellschaftsrecht”, Entwicklungen im Gesellschaftsrecht XII, Stämpfli Verlag AG, 2017, s. 176.

8 Yasemin Maraşlı Dinç, Miras Hukukunda Külli Halefiyet İlkesi, Yayınlanmamış Yüksek Lisans Tezi, Ankara Hacı Bayram Veli Üniversitesi Lisansüstü Eğitim Enstitüsü, Ankara, 2020, s. 52.

9 Handschin, Auflösung, s. 216; Yavuz/Acar/Özen, s. 1525. 
bir hüküm konulması da mümkündür ${ }^{10}$. Bu ihtimalde, ortaklık sağ kalan ortaklarla devam eder. Ölen ortağın tasfiye payı ise bir alacak hakkı olarak onun terekesinin aktif kısmına girer ve mirasçılar tarafından talep edilebilir. Sözleşmede ortağın ölümüne ilişkin herhangi bir hüküm bulunmamakla birlikte, ölen ortağın mirasçılarıyla diğer ortak veya ortakların oybirliğiyle anlaşmaları sonucunda adi ortaklık devam ettirilebilir ${ }^{11}$.

\section{TASFIYY SÜRECINDE MİRASÇILARIN DURUMU}

\section{A. Genel Olarak}

Adi ortaklığın bir ortağın ölümü sebebiyle sona ermesi, ortaklık ilişkisinin kendiliğinden çözülmesi anlamına gelmez ${ }^{12}$. Zira bu noktadan sonra, ortaklığın tasfiye sürecine girmesi ve ortaklık varlığının net olarak tespit edilmesi gerekmektedir. Tasfiye (Liquidation) genel itibariyle, ortaklık mal varlığının tespit edilerek borçların ödenmesinden sonra geriye kalan miktarın sözleşmede veya kanunda düzenlenen şekilde paylaştırılmasıdır ${ }^{13}$. Şu halde, tasfiyenin nasıl yapılacağına dair sözleşmede bir hüküm bulunduğu takdirde, öncelikle bu hükme göre hareket edilmesi gerekmektedir. Mirasçılar da ölen ortağın taraf olduğu bu hüküm ile bağlıdırlar. Dolayısıyla mirasçılar, sözleşmede hüküm bulunmasına rağmen, tasfiyenin kanun hükümlerine göre yapılmasını isteyemezler. Tasfiye usulüne ilişkin kanun hükümleri (TBK m. 642, 643, 644), tamamlayıc1 niteliktedir ${ }^{14}$. Bu sebeple, adi ortaklık

10 Handschin/Vonzun, ZK-OR, Art. 545, N. 36; Oruç Hami Şener, Adi Ortaklık, 1. Bask1, Yetkin Yayınları, Ankara, 2008, s. 445; Simge Aksu, Adi Ortaklığın Sona Erme Sebepleri, Yayınlanmamış Yüksek Lisans Tezi, Dokuz Eylül Üniversitesi Sosyal Bilimler Enstitüsü, İzmir, 2011, s. 39.

11 Şener, s. 448; Aksu, s. 45; Wolf, s. 80.

12 "Adi ortaklığın sona ermesinin en önemli sonuçlarından biri ortaklığın tasfiye aşamasına girmesidir. Zira sona erme sebeplerinden birinin gerçekleşmesiyle birlikte, adi ortakllk hemen ortadan kalkmaz; sadece sona erme sebeplerinin varlığl ortaklık bünyesinde bir takım değişikler meydana getirerek, ortaklı̆̆ın tasfiye aşamasına girmesine neden olur. Ortaklar arasındaki hukuki bağ, tasfiyenin tamamlanması ile ortadan kalkar”. Yarg. 3. HD, E. 2013/3554, K. 2013/6981, T. 29.4.2013.

13 "Tasfiye, ortaklı̆̆ın bütün malvarlığının belirlenip, ortakların birbirleri ile alacak verecek ve ortaklıktan doğan tüm ilişkilerinin kesilmesi yoluyla ortaklığın sonlandırılması, malların paylaşılması ya da satış yoluyla elden çıkarılmasıdır. Diğer bir anlatımla tasfiye memuru tarafindan yapılacak bir arıtma işlemi olup; hesap ve işlemlerin incelenip, bir bilanço düzenlenerek, ortaklığın aktif ve pasifi arasındaki farkı ortaya koymaktır”. Yarg. 3. HD, E. 2014/2569, K. 2014/6532, T. 29.4.2014.

14 Mehmet Ali Aykun, Adi Ortaklığın Sona Ermesi ve Tasfiyesi, Yayınlanmamış Yüksek Lisans Tezi, Erciyes Üniversitesi Sosyal Bilimler Enstitüsü, Kayseri, 2019, s. 82. 
sözleşmesinde tasfiye usulüne ilişkin hüküm bulunmasa bile, ortaklar tasfiyenin nasıl yapılacağı konusunda anlaşarak kanunda düzenlenenden farklı bir usul benimseyebilirler ${ }^{15}$.

\section{B. Ortaklığın Geçici Yönetimi}

\section{Bildirim Yükümlülüğü}

Türk Borçlar Kanunu m. 641/2 (OR Art. 547, Abs. 3) hükmüne göre, adi ortaklığın ortaklardan birinin ölümü sebebiyle sona ermesi halinde, ölen ortağın mirasçısı durumu hemen diğer ortaklara bildirmekle yükümlüdür (Mitteilungspflicht)16. Dikkat edilirse hükmün lafzında yalnızca "mirasçı" ifadesine yer verilmiştir. Ölen ortağın tek mirasçısı varsa, bu mirasçının bildirim yükümlülüğ̈̈ noktasında ihtilaf meydana gelmez. Ancak birden fazla mirasçının var olması halinde, bildirim yükümlülüğ̈̈nün nasıl yerine getirileceği bakımından tereddüt meydana gelebilir. Öğretide bir görüş, birden fazla mirasçının var olduğu hallerde bildirim yükümlülüğünün birlikte yerine getirilmesi gerektiğini ifade etmektedir ${ }^{17}$. Söz konusu görüş, miras ortaklı̆̆ına hâkim olan elbirliği ilkesine uygun görünmektedir. Hal böyle olmakla birlikte, mirasçıların her durumda birlikte hareket etmeleri mümkün olmayabilir. Kanunda mirasçılardan her birinin terekedeki hakların korunmasını isteyebileceği düzenlenmiştir (TMK m. 640/4). Şu halde, terekedeki hakların korunması bakımından her bir mirasçı bunun için gerekli işlemleri tek başına yapabilir. Bu sebeple, birden fazla mirasçının bulunduğu hallerde dahi mirasçılardan birinin ortağın ölümünü diğer ortaklara bildirebileceğini kabul etmek gerekir $^{18}$.

Bildirim yükümlülüğü bir irade beyanı değil, davranışta bulunma yükümlülüğüdür ${ }^{19}$. Bu sebeple bildirim, bütün ortaklara gönderildiği anda yükümlülük yerine getirilmiş olunur. Bildirimin ulaşmamasına ilişkin riski

15 Aykun, s. 82.

16 Christ, SHK-OR, Art. 547, N. 3; Müller, OFK-OR, Art. 547, N. 2; Handschin/Vonzun, ZK-OR, Art. 545-546-547, N. 40. Esasen bildirim yükümlülüğü, yalnızca mirasçılara ait bir yükümlülük değildir. Her bir ortak, kendisi tarafından bilinen sona erme sebebini derhal diğer ortaklara bildirmek durumundadır. Ancak ölüm durumunda bildirim yükümlülüğü aynı zamanda ölen ortağın mirasçılarına da yüklenmiştir.

17 Aykun, s. 78.

18 Handschin/Vonzun, ZK-OR, Art. 545-546-547, N. 40. Yazarlara göre, mirası kabul edip etmeyeceği belli olmayan veya mirası reddetme niyetinde olan mirasçılar bakımından da bildirim yükümlülüğü bulunmaktadır.

19 Handschin/Vonzun, ZK-OR, Art. 545-546-547, N. 40. 
mirasçılar değil ortaklar taşı1 ${ }^{20}$. Öte yandan mirasçıların yaptıkları bildirim açıklayıcı niteliktedir. Dolayısıyla, ortağın ölümü sebebiyle ortaklığın sona ermesi bildirimin ulaştığı anda değil, ortağın ölümü anında gerçekleşir ${ }^{21}$.

\section{2. İşleri Yönetme Yükümlülüğü}

Ortaklardan birinin ölümü ve ortaklığın sona ermesiyle birlikte, esasen ortaklı̆̆ın amacı tasfiye amacına dönüşür ve bu çerçevede ortakların yönetim yetkileri de tasfiyenin gerçekleşmesiyle sınırlıdır ${ }^{22}$. Hal böyle olmakla birlikte, tasfiye işlemlerine kısa bir süre içerisinde başlanması mümkün olmayabilir. $\mathrm{Bu}$ sebeple, tasfiye sürecinin başlamasına kadar ortaklıkla ilgili sürdürülmesi zorunlu olan işler bulunabilir. TBK m. 641/2 hükmü gereğince mirasç1, gerekli önlemler alınıncaya kadar, ölen ortağın daha önce yürütmekte olduğu işlere, dürüstlük kuralı çerçevesinde devam edecektir (Geschäftsführungspflicht) ${ }^{23}$.

Ölen ortağın daha önce yürütmekte olduğu işler bakımından bütün mirasçıların birlikte hareket etmeleri gerekmektedir. Mirasçılar, söz konusu işlerin içlerinden biri tarafından yürütülmesi konusunda anlaşma yapabilirler. $\mathrm{Bu}$ hususta anlaşmaya varılamaması durumunda ise, mirasçılardan birinin talebi üzerine sulh mahkemesi tarafindan miras ortaklığına temsilci atanabilir (TMK m. 640/3). Temsilci atanması durumunda, ölen ortağın işleri temsilci tarafindan devam ettirilir.

Ölen ortağın daha önce yürütmekte olduğu işlerin devam ettirilmesi bakımından kanunda dürüstlük kuralına atıf yapılmıştır (TBK m. 641/2).

20 Handschin/Vonzun, ZK-OR, Art. 545-546-547, N. 40.

21 Ancak bu ihtimalde, özellikle yönetici ortaklar bakımından yönetim yetkisinin ortadan kalkması, ortaklığın sona erdiğini, diğer bir deyişle ortağın ölümünü öğrenmesine bağlıdır. Bu sebeple TBK m. 641/1 (OR Art. 547, Abs. 1) hükmünde, yönetici ortaklar bakımından koruyucu nitelikte bir hüküm getirilerek, ortaklık işlerini yönetme yetkisinin sona ermenin öğrenildiği veya durumun gerektirdiği özeni gösterseydi öğrenebileceği zamana kadar devam edeceği belirtilmiştir. Bkz: Müller, OFK-OR, Art. 547, N. 2; Jung, CHK-OR, Art. 547-551, N. 7.

22 Christ, SHK-OR, Art. 547, N. 4; Müller, OFK-OR, Art. 547, N. 1; Jung, CHK-OR, Art. 547551, N. 5.

23 Handschin/Vonzun, ZK-OR, Art. 545-546-547, N. 42. Ölen ortağın mirasçılarının işleri yönetme yükümlülüğü, vekâlet sözleşmesine ilişkin TBK m. 513/2 (OR Art. 405, Abs. 2) hükmü ile bağlantılıdır. İlgili hükme göre vekâletin sona ermesi vekâlet verenin menfaatlerini tehlikeye düşürüyorsa, vekâlet veren veya mirasçısı ya da temsilcisi, işleri kendi başına görebilecek duruma gelinceye kadar, vekil veya mirasçısı ya da temsilcisi, vekâleti ifaya devam etmekle yükümlüdür. Bkz: Müller, OFK-OR, Art. 547, N. 3. Ancak geçici olarak işleri yürütme yükümlülügünün vekâletsiz işgörme kapsamında olduğu da ileri sürülmektedir. Bkz: Jung, CHK-OR, Art. 547-551, N. 8. 
Dolayısıyla mirasçılar, ölen ortağın işlerinin devamında belirli bir özen ölçüsünde hareket etmek durumundadırlar. Ancak burada ifade olunan özen sübjektif niteliktedir. Diğer bir deyişle, mirasçıların kişisel becerileri ve durumları çerçevesinde işleri devam ettirmeleri söz konusu olacaktır ${ }^{24}$. Ancak öğretide, işleri yönetme yükümlülügünün ortaklık sözleşmesinde verilen yönetim yetkisiyle sınırlı olmayıp, ölen ortağın ortaklık ilişkisi çerçevesinde ilgilenmesi gereken bütün işleri kapsadığı ifade edilmektedir ${ }^{25}$. Zaman bakımından ise, ölen ortağın ölümü anında yürütmekle yükümlü olduğu işlerin kapsamı göz önünde tutulacaktır ${ }^{26}$. Mirasçıların, ölen ortağın yönetim yükümlülüğünü aşacak şekilde işleri devam ettirmekle sorumlu tutulması mümkün değildir.

Mirasçıların işleri yönetme yükümlülüğü, TBK m.641/2'de belirtildiği üzere, "gerekli önlemler alınıncaya kadar" devam etmektedir. Ancak hükümde kastedilen husus, sağ kalan ortakların yönetimi etkin bir biçimde devralmaları değil, işleri yürütme imkânlarının var olmasıdır ${ }^{27}$. Dolayısıyla sağ kalan ortaklar, ortaklığın içyapısı itibariyle mirasçılar olmaksızın ölen ortağın daha önce yürüttüğü işlere devam edebiliyorsa, mirasçıların yönetim yükümlülüğü sona erecektir ${ }^{28}$.

Mirasçıların ortağın ölümünü zamanında diğer ortaklara bildirmemeleri ya da ortağın işlerine geçici olarak devam etmemeleri sebebiyle ortaklığın zarara uğraması durumunda, mirasçılar bu zararı gidermekle yükümlü olacaklardir ${ }^{29}$.

\section{Tasfiye Aşaması}

\section{Tasfiyede Mirasçıların Rolü}

Türk Borçlar Kanunu m. 644/1 (OR Art. 550, Abs. 1) hükmünde, adi ortaklığın tasfiyesinin bütün ortakların elbirliğiyle yapılacağı düzenlenmiştir.

\footnotetext{
24 Aykun, s. 78. Abs. 2).

26 Handschin/Vonzun, ZK-OR, Art. 545-546-547, N. 42.

27 Handschin/Vonzun, ZK-OR, Art. 545-546-547, N. 43.

28 Handschin/Vonzun, ZK-OR, Art. 545-546-547, N. 43.

29 Handschin/Vonzun, ZK-OR, Art. 545-546-547, N. 41.
}

25 Handschin/Vonzun, ZK-OR, Art. 545-546-547, N. 42. Alman Medeni Kanunu'nun ayn1 konuyu düzenleyen 727. paragrafında ise, mirasçıların yalnızca ortaklık sözleşmesi ile ölen ortağa devredilmiş olan işleri yürütmekle yükümlü oldukları belirtilmektedir (BGB § 727, 
Söz konusu hüküm ilk bakışta ölen ortağın mirasçılarının tasfiyeye katılmayacakları izlenimini uyandırmaktadır. Zira ortağın ölümüyle birlikte adi ortaklık sona erdiği takdirde, ölen ortağın ortaklık sıfatı mirasçılara intikal etmemektedir. Tasfiyeye katılma, ortaklık sıfatına bağlı bir hak ve görevdir. Hal böyle olmakla birlikte, ortaklığın tasfiyesi esasen ekonomik bir süreci ifade eder. Tasfiye neticesinde ortaya çıkacak durum, ortakların malvarlıklarıyla ilişkilidir. Mirasçılar, ölen ortağın malvarlıksal durumuna halef olduklarına göre, tasfiyeye katılmaları gerekmektedir ${ }^{30}$.

Ortağın ölümüyle birlikte ortaklığın sona erdiği hallerde, adi ortaklık bir tasfiye ortaklığına (Liquidationsgesellschaft) dönüşmektedir ${ }^{31}$. Şu halde ölen ortağın mirasçıları da bu tasfiye ortaklığının üyesi olmaktadır. Ölen ortağın tek mirasçısının var olduğu hallerde, tasfiyenin yürütülmesi bakımından bir sorun yaşanmaz. Ancak birden fazla mirasçı varsa, bunların birlikte hareket etmeleri gündeme gelecektir. Zira mirasçılar tasfiye ortaklığına ayrı ayrı değil, miras ortaklığı halinde girmektedirler. İsviçre öğretisinde, ölen ortağın birden fazla mirasçısı bulunduğu takdirde, bunların tasfiyeyi yürütmek için bir temsilci (Erbenvertreter) atamaları gerektiği ifade edilmektedir ${ }^{32}$. Söz konusu yazarlar, İsviçre Borçlar Kanunu (OR) m. 584 hükmünün adi ortaklığa kıyasen uygulanacağı noktasında hemfikirdir. Bahsi geçen hüküm, kollektif ortaklığın tasfiyesi halinde ortaklardan birinin mirasçılarının tasfiye için ortak bir temsilci tayin etmek zorunda olduklarını belirtmektedir ${ }^{33}$. İsviçre Federal Mahkemesi de vermiş olduğu bir kararda, mirasçıların tasfiye bakımından ölen ortağın hukuki konumuna halef olarak tasfiye ortaklığına dâhil olacaklarını fakat OR 584 hükmüne kıyasen ortak bir temsilci atanması gerektiğini ifade etmiştii ${ }^{34}$. Hal böyle olmakla birlikte, OR 584 hükmünde ortak temsilcinin nas1 tespit edileceği düzenlenmemiştir. Bu konuda İsviçre Medeni Kanunu (ZGB) m.

30 Wolf, s. 81; Müller, OFK-OR, Art. 550, N. 2; Handschin/Vonzun, ZK-OR, Art. 548-551, N. 19; Thomas A. Steininger, SHK - Stämpflis Handkommentar, Personengesellschaftsrecht (Art. 530-619 OR), Stämpfli Verlag AG, 2015, Art. 550, N. 2.

31 Müller, OFK-OR, Art. 550, N. 2.

32 Jung, CHK-OR, Art. 547-551, N. 9; Steininger, SHK-OR, Art. 550, N. 2; Müller, OFK-OR, Art. 550, N. 2; Handschin/Vonzun, ZK-OR, Art. 548-551, N. 20; Wolf, s. 81.

33 Andreas Casutt, OFK - Orell Füssli Kommentar, Schweizerisches Obligationenrecht, 3. Auflage, Orell Füssli Verlag AG, 2016, Art. 584, N. 1; Reto Strittmatter, CHK Handkommentar zum Schweizer Privatrecht, Personengesellschaften und Aktiengesellschaft - Vergütungsverordnung, 3. Auflage, Schulthess Juristische Medien AG, 2016, Art. 584, N. 2; Steininger, SHK-OR, Art. 584, N. 4.

34 BGE 119 II 119. 
$602 / 3$ hükmü uygulanacaktır ${ }^{35}$. Tasfiyede mirasçıları temsil edecek kişi, bütün mirasçıların veya yasal temsilcilerinin oybirliğiyle seçilmelidir ${ }^{36}$. Sağ kalan ortaklar, mirasçılara temsilci atamaları için makul bir süre tanımalıdır. Ancak temsilci atanmasının uzun sürmesi sebebiyle sağ kalan ortaklar zarara uğrarsa, bunun giderilmesini mirasçılardan talep edebilirler ${ }^{37}$. Mirasçılar tasfiye için temsilci seçme konusunda anlaşamazlarsa, mirasçılardan birinin talebi üzerine yetkili makam tarafından miras ortaklığına bir temsilci atanacaktır (ZGB Art. 602, Abs. 3) ${ }^{38}$. Yetkili makam, talebin içeriğine göre genel bir tereke temsilcisi atayabileceği gibi, yalnızca ortaklığın tasfiyesine katılımla sınırlı olarak da atama yapabilir.

Türk Hukuku bakımından İsviçre Borçlar Kanunu m. 584 hükmüne benzer bir düzenleme bulunmamaktadır. Hal böyle olmakla birlikte, İsviçre öğretisi ve Federal Mahkeme tarafindan kabul edilen çözüm, Türk Hukuku için de benimsenebilir. Aksi takdirde, mirasçıların tamamının tasfiye sürecine birlikte katılması gerekecek ve bu durum zaten karmaşık olan tasfiyeyi daha da zorlaştıracaktır. Mirasçıların tasfiye için temsilci belirleme konusunda anlaşamamaları durumunda, içlerinden birinin talebiyle mahkeme tarafindan tereke temsilcisi atanması imkânı kanunda vardır (TMK m. 640/3). Mirasçılar dışında sağ kalan ortakların terekeye temsilci atanmasını talep etmeleri mümkün değildir. Zira terekeye temsilci atanmasını talep etme yetkisi, yalnızca kanuni ve atanmış mirasçılara aittir ${ }^{39}$. Mirasçıların bu konuda talepte bulunmamaları halinde, sağ kalan ortaklar ancak hâkim tarafından tasfiye görevlisi atanmasını (TBK m. 644/2) ya da tasfiyenin hâkim tarafindan gerçekleştirilmesini isteyebilirler (TBK m. 644/4).

Tasfiyede miras ortaklığını temsil edecek kişi, mirasçılar arasından seçilebileceği gibi, üçüncü bir kişinin seçilmesi de mümkündür ${ }^{40}$. Mahkeme

35 Lukas Handschin/Han-Lin Chou, ZK - Zürcher Kommentar, Kommentar zum schweizerischen Zivilrecht, Die Kollektivgesellschaft, Die Kommanditgesellschaft, Art. 552-619 OR, 4. Auflage, Schulthess Juristische Medien AG, 2009, Art. 584, N. 6; Steininger, SHK-OR, Art. 584, N. 5; Casutt, OFK-OR, Art. 584, N. 2.

36 Steininger, SHK-OR, Art. 584, N. 5; Handschin/Chou, ZK-OR, Art. 584, N. 6.

37 Handschin/Chou, ZK-OR, Art. 584, N. 7.

38 Steininger, SHK-OR, Art. 584, N. 6; Handschin/Chou, ZK-OR, Art. 584, N. 7.

39 Sezer Çabri, Miras Hukuku Şerhi, Cilt-III, 1. Baskı, İstanbul, 2020, s. 53; Zahit İmre/ Hasan Erman, Miras Hukuku, 13. Bas1, İstanbul, 2017, s. 449; O. Gökhan Antalya/İpek Sağlam, Miras Hukuku, 4. Bası, Seçkin Yayınları, Ankara, 2019, s. 482; Ali Naim İnan/Şeref Ertaş/Hakan Albaş, Miras Hukuku, 10. Bası, Seçkin Yayınları, Ankara, 2019, s. 556; Rona Serozan/Baki İlkay Engin, Miras Hukuku, 6. Bası, Seçkin Yayınları, Ankara, 2019, s. 570.

40 Strittmatter, CHK-OR, Art. 584, N. 2. 
(İsviçre Hukukunda yetkili makam) tarafından temsilci atanması durumunda ise, bu kişinin mirasçılar dışından seçilmesi daha uygun olacaktır ${ }^{41}$. Ölen ortak tarafindan vasiyeti yerine getirme görevlisi (Willensvollstrecker) atandı̆̆ 1 ya da terekenin resmi idaresinin (amtlicher Verwaltung) söz konusu olduğu hallerde ise, tasfiye işlemleri için temsilci seçilmesine gerek kalmayacaktır ${ }^{42}$.

Temsilcinin temel görevi, miras ortaklığının tasfiye edilecek ortaklıktaki haklarını korumak ve gözetmektir ${ }^{43}$. Temsilcinin tasfiye sürecindeki iradesi, bütün mirasçıların iradeleri yerine geçer. $\mathrm{Bu}$ sebeple, mirasçılar temsilcinin yapmış olduğu işlemlerle bağlıdırlar ${ }^{44}$. Böylelikle, diğer ortaklar çok sayıda mirasçı ile ayrı ayrı müzakerede bulunmaktan kurtulmuş ve tasfiye ile ilgili karar verme süreci hızlandırılmış olmaktadır ${ }^{45}$.

\section{Mirasçıların Denetim Hakkı}

Adi ortaklıkta her ortak, yönetim yetkisi olmasa bile ortaklığın işleyiş̧i hakkında bilgi alma, defter ve kayıtları inceleme, bunlardan örnek alma ve mali durumu hakkında özet çıkarma hakkına sahiptir (TBK m. 631/1, OR Art. 541, Abs. 1) $)^{46}$. Mutlak nitelikte ortaksal bir hak olan denetim hakk1 ${ }^{47}$, bu özelliği bakımından ortaklık sıfatıyla doğrudan bağlantılıdır. Hal böyle olmakla birlikte, ortaklardan birinin ölümüyle ortaklığın sona erdiği hallerde, mirasçıların tasfiye aşamasında kendi menfaatlerini korumak için denetim hakkına ihtiyaçları bulunmaktadır ${ }^{48}$. Bu sebeple, ölen ortağın mirasçılarının da denetim hakkından yararlanabilecekleri kabul edilmelidir. İsviçre öğretisinde, ortağın ölümü sebebiyle ortaklığın tasfiyeye girmesi halinde mirasçıların denetim hakkının temsilci tarafından kullanılacağı belirtilmektedir ${ }^{49}$. Benzer

${ }_{41}$ Steininger, SHK-OR, Art. 584, N. 8; Handschin/Chou, ZK-OR, Art. 584, N. 8.

42 Steininger, SHK-OR, Art. 584, N. 7; Strittmatter, CHK-OR, Art. 584, N. 2; Handschin/ Chou, ZK-OR, Art. 584, N. 8; Casutt, OFK-OR, Art. 584, N. 2.

43 Strittmatter, CHK-OR, Art. 584, N. 3.

44 Handschin/Chou, ZK-OR, Art. 584, N. 9.

45 Casutt, OFK-OR, Art. 584, N. 2.

46 Felmann/Müller, BK-OR, Art. 541, N. 7; Jung, CHK-OR, Art. 541, N. 1; Müller, OFK-OR, Art. 541, N. 1; Handschin/Vonzun, ZK-OR, Art. 541, N. 1; Florian S. Jörg, SHK - Stämpflis Handkommentar, Personengesellschaftsrecht (Art. 530-619 OR), Stämpfli Verlag AG, 2015, Art. 541, N. 1.

47 Ali Haydar Yıldırım, "Adi Ortaklıkta Ortakların Denetleme Hakkı (TBK 631)", Dokuz Eylül Üniversitesi Hukuk Fakültesi Dergisi, C. 13, S. 2, 2011, s. 198.

48 Yıldırım, s. 206; Jörg, SHK-OR, Art. 541, N. 9; Felmann/Müller, BK-OR, Art. 541, N. 32.

49 Müller, OFK-OR, Art. 541, N. 5; Felmann/Müller, BK-OR, Art. 541, N. 32; Strittmatter, 
bir durum, vasiyeti yerine getirme görevlisinin atandığ hallerde de geçerlidir ${ }^{50}$.

Mirasçıların tasfiye işlemlerinin denetimine olanak tanıyacak olanlar yöneticilerdir ${ }^{51}$. Ancak tasfiye işlerinin yürütülmesi için bir tasfiye görevlisi atanmışsa, mirasçılar tasfiye görevlisinden denetim hakkının kullanılmasına imkân tanımasını talep edebilirler ${ }^{52}$. Ancak mirasçıların denetim hakkı, yalnızca tasfiyenin yürütülmesiyle sınırlıdır ${ }^{53}$. Bu bakımdan mirasçılar, ölen ortağın tasfiye payının nasıl tespit edildiğiyle ilgili hususlarda bilgi alma ve özellikle de tasfiyede tutulan defter ve kayıtları inceleme hakkına sahiptirler.

\section{Tasfiyenin Gerçekleştirilmesi ve Sonucu}

Kanunda tasfiyenin gerçekleşmesi bakımından bütün ortakların elbirliğiyle yapılması öngörülmüştür (TBK m. 644/1, OR Art. 550, Abs. 1) $)^{54}$. Hal böyle olmakla birlikte, pratik açıdan bu durum oldukça zordur. Söz konusu zorluğu aşabilmek adına kanunda, ortakların tasfiye işlerini yürütmek üzere tasfiye görevlisi atayabilecekleri ifade edilmektedir (TBK m. 644/2). Tasfiye görevlisi, ortaklık sözleşmesi ile de atanabilir. Başka bir ifadeyle, ortaklar adi ortaklık sözleşmesine koyacakları bir hükümle, kendi içlerinden veya üçüncü kişilerden bir ya da birkaç kişiyi tasfiye görevlisi olarak belirleyebilirler ${ }^{55}$.

Ortaklardan birinin ölümü sebebiyle tasfiyeye gidilmesi durumunda, ortaklık sözleşmesinde tasfiye görevlisi belirlenmemişse, diğer ortakların ve mirasçıların oybirliğiyle tasfiye görevlisinin atanması gerekmektedir. $\mathrm{Bu}$ konuda anlaşmaya varılamaması durumunda, ortaklardan her birinin tasfiye

CHK-OR, Art. 584, N. 3.

50 Felmann/Müller, BK-OR, Art. 541, N. 35-36.

51 "Protokolde adi ortaklardan birinin ölümü halinde ortaklı̆̆ın devamına ilişkin bir kayıt bulunmamaktadır. Bu nedenle ortaklık davacıların murisinin ölümü ile son bulmuştur. Davalının idareci ortak olduğu düzenlenen protokol ve ödeme makbuzundan anlaşllmaktadır. Kural olarak idareci ortağın hesap verme yükümlülüğ̈̈ vardır. Davalı idareci ortak, adi ortaklığın sona erip tasfiyenin yapıldı̆̆ını kanıtlamamıştır”. Yarg. 13. HD, E. 2001/324, K. 2001/2226, T. 1.3.2001.

52 Yildırım, s. 212.

53 Felmann/Müller, BK-OR, Art. 541, N. 32; Handschin/Vonzun, ZK-OR, Art. 541, N. 6; Jörg, SHK-OR, Art. 541, N. 9.

54 Handschin/Vonzun, ZK-OR, Art. 548-551, N. 55; Philip R. Bornhauser, "Gesamteigentum und einfache Gesellschaft: Vorrang sachenrechtlicher Bestimmungen bei der Liquidation", Aktuelle Juristische Praxis, 2014, Dike Verlag AG, s. 651.

55 Erol Ulusoy, “Adi Ortaklığın Tasfiyesi ve Mahkemelerin Görevi”, Uyuşmazlık Mahkemesi Dergisi, C. 5, S. I, 2015 , s. 889. 
görevlisinin hâkim tarafından atanmasını isteme hakkı bulunmaktadır (TBK m. 644/2). Haliyle, mirasçılar da tasfiye görevlisi atanması için mahkemeden talepte bulunabilirler.

Tasfiye görevlisinin atanması dışında, ortakların genel anlamda tasfiye usulü konusunda da anlaşmazlığa düşmeleri ihtimal dâhilindedir. Böyle bir durumda her bir ortak, mahkemeye başvurarak tasfiyenin hâkim tarafindan gerçekleştirilmesini isteyebilir (TBK m. 644/4) ${ }^{56}$. Tasfiye usulü konusunda sözleşmede bir hüküm bulunmadığı ve ortaklar arasında sonradan anlaşma sağlanamadığı durumlarda, kanunda yer alan düzenlemeler (TBK m. 642, $643,644)$ uygulama alanı bulacaktır.

Tasfiyede genel itibariyle öncelikle ortaklığın malvarlığı tespit edilir. Ortaklığın alacakları tahsil edilip borçları ifa edildikten sonra, ortaklardan her birine ortaklığa verdiği avanslarla ortaklık için yaptığı giderler ödenir (TBK m. 643/1, OR Art. 549, Abs. 1) ${ }^{57}$. Sonrasında geriye bir şey kalırsa, ortakların her birine ortaklığa koydukları katılma payları ödenir ${ }^{58}$. Bu bakımdan ölen ortağın katılma payının da onun mirasçılarına ödenmesi gerekmektedir. Mirasçılar söz konusu katılma payı üzerinde elbirliği halinde hak sahibidirler.

Ortaklığın, borçlar, giderler ve avanslar ödendikten sonra kalan varlığının ortakların katılma paylarının ödenmesine yetmemesi durumunda, zarar ortaklar arasında paylaşılacaktır (TBK m. 643/2, OR Art. 549, Abs. $2)^{59}$. Bu durumda mirasçılar da ölen ortağın payına düşen oranda zarara katlanacaklardır. Zira mirasçılarölen ortağın ortaklık sıfatına halef olmasalar da adi ortaklıktaki malvarlıksal durumuna haleftirler. Kanunda, sözleşmede aksi kararlaştırılmadığı takdirde, her ortağın kazanç ve zarardaki payının, katılma payının değerine ve niteliğine bakılmaksızın eşit olduğu düzenlenmiştir (TBK

56 Ulusoy, s. 891; Aykun, s. 88. "Adi ortaklı, ortakların anlaşması durumunda, onların kendi aralarında tasfiye edilebilir. Şayet ortaklar arasında tasfiye konusunda anlaşma sağlanamamışsa, bu durumda her ortağın mahkemeye başvurarak tasfiye talebinde bulunabileceğini kabul etmek gerekir. Bu başvuru açıkça ortaklığın tasfiyesini istemek şeklinde olabileceği gibi, tasfiyeyi ifade eden başkaca talepler de tasfiye yapılması için yeterlidir. Örneğin; ortaklı̆̆ın feshi istemi veya ortaklı̆̆a getirilen sermayenin iadesinin talep edilmesi, ortaklığın tasfiyesini isteme anlamına gelir". Yarg. 3. HD, E. 2020/2560, K. 2020/4057, T. 14.9.2020.

57 Yavuz/Acar/Özen, s. 1527.

58 Tasfiye işlemlerinin sırası hakkında bkz: Ulusoy, s. $894 \mathrm{vd}$.

59 Handschin/Vonzun, ZK-OR, Art. 548-551, N. 191; Jung, CHK-OR, Art. 547-551, N. 13; Müller, OFK-OR, Art. 549, N. 7; Steininger, SHK-OR, Art. 548-549, N. 16. 
m. 623/1, OR Art. 533, Abs. 1) $)^{60}$.

Katılma paylarının ödenmesinden sonra geriye bir şey kalırsa, bu değer ortaklığın kazancı olarak nitelenir ve ortaklar arasında paylaşılır (TBK m. 643/1). Kazancın paylaşılması noktasında da TBK m. 623 hükmü geçerlidir. Başka bir ifadeyle, sözleşmeyle aksi kararlaştırılmadığı takdirde, elde edilen kazanç ortaklar arasında eşit olarak dağıtılacaktır. Ölen ortağın payına düşen kazanç, onun terekesinin aktifinde yer alır. Mirasçılar diğer ortaklara karşı ölen ortağın tasfiye sonucu elde edilen payının ifa edilmesini talep edebilirler. Katılma payında olduğu gibi, tasfiye payında da mirasçıların elbirliği halinde hak sahipliği söz konusudur.

Ortaklığın malvarlığının borçların ödenmesine yetmemesi durumunda, bütün ortakların müteselsilen sorumlu olmaları söz konusudur. Zira kanunda, ortakların birlikte veya bir temsilci aracılı̆̆ıyla üçüncü kişiye karşı ortaklık ilişkisi çerçevesinde üstlendikleri borçlardan, aksi kararlaştırılmadığ takdirde müteselsilen sorumlu oldukları açıkça düzenlenmiştir (TBK m. 638/3, OR Art. 544, Abs. 3) ${ }^{61}$. Burada doğrudan doğruya kanundan doğan bir sorumluluk türü bulunmaktadır. Alacaklılar, alacağın tamamını ortakların tamamından, birkaçından ya da her birinden talep edebilirler ${ }^{62}$. Ortaklar, adi ortaklığın borcundan dolayı şahsen sorumlu olduklarından, ölen ortağın borçlardan sorumluluğu kendi mirasçılarına geçecektir. Şu halde adi ortaklığın alacaklıları, isterlerse alacaklarının tamamını ölen ortağın mirasçılarından talep edebilecektir. Mirasçılar, ölen ortağın payına düşen kısımdan fazlasını ödedikleri takdirde, diğer ortaklara rücu etme hakkına (Rückgriffsrecht)

60 Fellmann/Müller, BK-OR, Art. 533, N. 9; Handschin/Vonzun, ZK-OR, Art. 533, N. 41; Müller, OFK-OR, Art. 533, N. 3; Jung, CHK-OR, Art. 533, N. 2; Dorothea Herren, SHK Stämpflis Handkommentar, Personengesellschaftsrecht (Art. 530-619 OR), Stämpfli Verlag AG, 2015, Art. 533, N. 31.

${ }_{61}$ Truniger, Präjudizienbuch OR, Art. 544, N. 7; Müller, OFK-OR, Art. 544, N. 8; Fellmann/ Müller, BK-OR, Art. 544, N. 18; Handschin/Vonzun, ZK-OR, Art. 544, N. 44-45; Frédéric Krauskopf/ Soluna Girón, SHK - Stämpflis Handkommentar, Personengesellschaftsrecht (Art. 530-619 OR), Stämpfli Verlag AG, 2015, Art. 544, N. 13.

62 Kural bu olmakla birlikte, alacağın konusunu oluşturan edim bütün ortakların birlikte hareket ederek gerçekleştirebilecekleri bir edimse, alacağın bütün ortaklardan talep edilmesi gerekmektedir. Söz gelimi, adi ortaklığın ifa etmesi gereken edim, bir taşınmazın mülkiyetinin devriyse, elbirliği ilkesi sebebiyle bu edim ancak bütün ortakların katılımıyla gerçekleşebilir. Bu sebeple, böyle bir talebin bütün ortaklara yöneltilmesi zorunludur. Ayrıntılı bilgi için bkz: Vildan Peksöz, Medeni Usul Hukuku Açısından Adi Ortaklık İlişkileri, 1. Bask1, İstanbul, 2020, s. 182 vd. 
sahiptirler ${ }^{63}$. Adi ortaklıkta müteselsil borçlu olan ortakların, iç ilişkide bu borcu nasıl paylaşacakları konusunda öncelikle ortaklık sözleşmesine bakılmalıdır ${ }^{64}$. Sözleşmede buna ilişkin bir hüküm yoksa ölen ortağın mirasçıları ile diğer ortakların, borçların ifa edilmesinden sonra da bu konuda anlaşmaları mümkündür. Böyle bir anlaşma söz konusu olmadığı takdirde, TBK m. 623/1 hükmü gereğince, ortakların katılma paylarının değerine ve niteliğine bakılmaksızın eşit oranda borca katlanmaları gerekecektir.

Mirasçıların diğer ortaklara rücu hakları var olduğu takdirde, bu hakkın kullanılması için açılacak davanın kural olarak bütün mirasçılar tarafından açılması gerekmektedir ${ }^{65}$. Zira rücu hakkına konu edilen alacak, ölen ortağın müteselsil sorumluluğu sebebiyle mirasçılar tarafından ifa edilmiştir. Şu halde, ölen ortağın payına düşen miktardan fazlası için talep edilecek rücu alacağ1 üzerinde bütün mirasçıların elbirliği halinde hak sahipliği bulunmaktadır. Ancak Yargıtay'ın içtihatlarına göre, terekeyle ilgili davanın mirasçılardan biri veya birkaçı tarafından açıldığı hallerde, mahkeme diğer mirasçıların da davaya katılması veya tereke temsilcisi atanması için davacı ya da davacılara süre vermelidir ${ }^{66}$.

Adi ortaklığın borçlarının ölen ortağın payına düşen kısmı, terekenin pasifinde yer alan bir unsur olarak mirasçılara intikal eder. Bu durum, biraz evvel bahsedilen rücu ilişkisi dışında ikinci bir rücu ilişkisinin ortaya çıkması sonucunu doğurabilir. Ancak söz konusu rücu ilişkisi, mirasçıların kendi aralarındaki ilişkidir. Ölen ortağın payına düşen borç, mirasçılardan biri veya birkaçı tarafından ödenmişse, borcu ödeyenlerin diğer mirasçı veya mirasçılara karş1 rücu hakk1 doğacaktır (TMK m. 682/1) ${ }^{67}$. Ancak bunun için, borcu ödeyen mirasçının kendi üzerine düşenden fazlasını ödemiş olması gerekir. Tereke borçları bakımından mirasçıların iç ilişkide hangi oranda sorumlu

63 Krauskopf/Girón, SHK-OR, Art. 544, N. 28; Handschin/Vonzun, ZK-OR, Art. 544, N. 83; Fellmann/Müller, BK-OR, Art. 544, N. 175; Jung, CHK-OR, Art. 544, N. 13.

64 Ömer Ali Girgin, Adi Ortaklıkta Temsil ve Borçlardan Sorumluluk, 1. Baskı, İstanbul, 2017, s. 128.

65 Terekeyle ilgili davaların kural olarak bütün mirasçılar tarafından açılacağı hakkında bkz: Çabri, s. 28; İmre/Erman, s. 441; Antalya/Sağlam, s. 477; İnan/Ertaş/Albaş, s. 553; Serozan/ Engin, s. 567.

66 Yarg. İBK, E. 1982/3, K. 1982/2, T. 11.10.1982; Yarg. 1. HD, E. 2016/16694, K. 2020/234, T. 16.1.2020; Yarg. 1. HD, E. 2019/95, K. 2020/5349, T. 22.10.2020; Yarg. 1. HD, E. 2017/2736, K. 2020/6053, T. 17.11.2020; Yarg. 1. HD, E. 2020/3758, K. 2021/1709, T. 24.3.2021.

${ }_{67}$ Antalya/Sağlam, s. 484; İmre/Erman, s. 457; Serozan/Engin, s. 112; Çabri, s. 90. 
olacakları üç şekilde tespit edilirr ${ }^{68}$. Birincisi, mirasbırakanın bu konuda bir ölüme bağlı tasarrufunun bulunmasıdır. İkincisi, mirasçıların tereke borcunun nasıl paylaşılacağı konusunda anlaşmalarıdır. Üçüncüsü ise, mirasçıların miras payları oranında sorumlu olmalarıdır. Şu halde, tereke borcunun mirasçılar arasında nasıl paylaşılacağ konusunda bir ölüme bağlı tasarruf ya da anlaşma yoksa her bir mirasçı iç ilişkide kendi miras payı oranında sorumlu olacaktır ${ }^{69}$.

Adi ortaklıkta tasfiyenin ortakların anlaşmaları çerçevesinde birlikte yapılması esastır. Hal böyle olmakla birlikte, ortağın ölümüyle beraber sona eren ortaklığın tasfiyesinde diğer ortakların tasfiye işlemlerini sürüncemede bırakmaları söz konusu olabilir. Mirasçılar, adi ortaklığın tasfiyesini ve bunun sonucunda ortaya çıkacak payın kendilerine ödenmesini ortaklardan talep edebilirler. Ancak ortakların bu talebi yerine getirmemeleri durumunda, mirasçıların mahkemeye başvurarak adi ortaklı̆̆ın tasfiyesini ve tasfiye çerçevesinde ortaya çıkacak payın ödenmesini dava edebileceklerini kabul etmek gerekmektedir ${ }^{70}$. Ne var ki, bu davanın kural olarak bütün mirasçılar tarafindan açılması gerekir ${ }^{71}$. Ayrıca, adi ortaklığın davada taraf olma ehliyeti (Parteifähigkeit) bulunmadığından ${ }^{72}$, davanın doğrudan diğer ortaklara yöneltilmesi zorunludur.

68 Çabri, s. 91.

69 Çabri, s. 91.

70 Ahmet Ayar, Adi Ortaklıkta İç ve Dış İlişkiler, 1. Bask1, İstanbul, 2019, s. 129.

71 Ayar, s. 129. "Adi ortaklığın, tüzel kişiliği yoktur. Tüzel kişiliği olmadığ için, taraf ehliyeti de yoktur. Bu itibarla, adi ortaklığa dair davalarda, adi ortaklığl oluşturan kişilerin taraf olarak hep birlikte hareket etmeleri gerekir. Adi ortakllktarafindan açılacak davaların, el birliği mülkiyeti kuralları gereğince bütün ortaklar tarafindan birlikte açılması gerekir. Bütün ortaklar tarafindan açılacak dava, adi ortaklık adına değil, bütün ortaklar adına açılır ve hüküm de ortaklar hakkında verilir. Aktif ve pasif taraf ehliyeti tüm ortaklara aittir. Bir ortağın, diğeri aleyhine açtı̆̆ davada, tüm ortaklar davaya dahil edilmelidir. Davada tarafların taraf ehliyetine sahip bulunmaları dava şartlarından olup, bu nedenle, mahkemece kendiliğinden re sen gözetilir. Tarafların babası, 01/04/2009 tarihinde öldüğüne göre, mahkemece öncelikle murisin tüm mirasçıların davaya dahil edilerek, taraf teșkilinin sağlanması, ardından tarafların tüm delilleri toplanarak, ortaklığın tasfiyesi hususu üzerinde durulması gerekir. Hal böyle olunca mahkemece; adi ortaklık ilişkisinde ortaklar arasında mecburi dava arkadaşlı̆̆ bulunduğu göz önünde bulundurularak, ölü ortağın mirasçıları davaya dahil edilmek suretiyle taraf teşkilinin sağlanması, ardından işin esası hakkında yapılacak yargilama neticesinde, tasfiye hususu üzerinde durularak, hasıl olacak sonuca göre bir karar verilmesi gerekirken, eksik inceleme sonucu taraf teşkili sağlanmadan, yazılı şekilde hüküm kurulması, usul ve yasaya aykırı görülmüş, bu husus bozmayı gerektirmiştir”. Yarg. 3. HD, E. 2017/11910, K. 2018/11790, T. 20.11.2018.

72 Reto Vonzun, "Die einfache Gesellschaft im Zivilprozess - ausgewählte Fragen", Theorie und Praxis des Unternehmensrechts Festschrift zu Ehren von Lukas Handschin, Schulthess Juristische Medien AG, 2020, s. 754. 


\section{III.ORTAKLIĞIN DEVAMI HALINDE MİRASÇILARIN DURUMU}

\section{A. Sözleşmede Mirasçılarla Devam Kaydının Bulunması}

Ortaklık sözleşmesinde ortaklardan birinin ölümü halinde ortaklık ilişkisininmirasçılarladevamettirilmesiyönündebirkayıtöngörülebilir. Nitekim kanunda bu duruma açıkça cevaz verilmektedir (TBK m. 639/1, b.2). Bununla birlikte, ortaklık sözleşmesinden ayrı bir sözleşmede de ortaklı̆̆ın mirasçılarla devamına karar verilmesi mümkündür (Fortsetzungsvereinbarung) ${ }^{73}$. Öğretide "halefiyet klozu (Nachfolgeklausel)" 74" ya da "halefiyet kayd1"75" olarak da adlandırılan bu tür kayıtların varlığı halinde, ortağın ölümünün ortaklığı sona erdiren bir sebep olmaktan çıkarıldığı kabul edilmektedir.

Mirasçılarla devam kaydı, kendi içerisinde "basit devam kaydı (einfache Nachfolgeklausel)" ve "nitelikli devam kayd1 (qualifizierte Nachfolgeklausel)" olmak üzere iki türe ayrılmaktadır ${ }^{76}$. Basit devam kaydı, ortaklığın bütün mirasçılarla devamını öngören kayıttır. Nitelikli devam kaydında ise, ortaklığın mirasçılardan yalnızca biri veya birkaçıyla devam ettirilmesi söz konusudur. Basit devam kaydında, ortağın ölümüyle birlikte bütün mirasçılar kendiliğinden adi ortaklığa girmektedirler. Nitelikli devam kaydında ise, bazı mirasçılar ortaklığa girerken, bazıları ortaklık dışında kalmakta fakat kendi miras payları oranında ayrılma payı alacağına hak kazanmaktadırlar.

Mirasçılarla devam kaydının varlığı, ölüm olgusunun ortaklığı sona erdirmesini engellese de, mirasçıların diğer ortaklarla ilişkileri noktasında muhtelif tartışmalara yol açmıştır. Tartışmaların temelinde, iki ayrı ortaklığın iç içe geçmesinin doğurduğu karmaşa yer almaktadır. Bir tarafta işlemesi gereken bir yapı olarak adi ortaklık bulunmaktadır. Diğer tarafta ise, bu ortaklığın birer parçasını oluşturan mirasçılardan teşekkül eden miras ortaklığ1 yer almaktadir.

73 Müller, OFK-OR, Art. 545, N. 4; Aksu, s. 41.

74 Christ, SHK-OR, Art. 545, N. 13; Müller, OFK-OR, Art. 545, N. 4; Handschin/Vonzun, ZK-OR, Art. 545, N. 36; Jung, Regelungen, s. 182; Türkmen, s. 136; Wolf, s. 87; Florent Thouvenin, Der Kooperationsvertrag, Kooperationen im Grenzbereich von Vertrags- und Gesellschaftsrecht, Stämpfli Verlag AG, 2017, s. 351.

75 Eren, Özel Hükümler, s. 884.

76 Eren, Özel Hükümler, s. 885; Thouvenin, s. 351; Handschin/Vonzun, ZK-OR, Art. 545, N. 36; Christ, SHK-OR, Art. 545, N. 13; Müller, OFK-OR, Art. 545, N. 4; Jung, Regelungen, s. 183-184. 


\section{Mirasçıların Kendiliğinden Ortaklık Sıfatının Kazanıp Kazanamayacakları Meselesi}

İlk olarak, mirasçılarla devam kaydı bulunduğu takdirde mirasçıların kendiliğinden ölen ortağın ortaklık sıfatını kazanıp kazanamayacakları tartışmalıdır. $\mathrm{Bu}$ noktada külli halefiyet ilkesiyle sözleşme özgürlüğü ilkesinin çatıştığı söylenebilir. Külli halefiyet ilkesine üstünlük tanınırsa, ortaklık sözleşmesinde mirasçılarla devam kaydının bulunduğu hallerde mirasçıların kendiliğinden ortaklık sıfatını kazanacakları sonucuna varmak gerekmektedir ${ }^{77}$. Sözleşme özgürlügü ilkesi bakımından düşünüldüğünde ise, mirasçıların kendiliğinden ortaklık ilişkisine dâhil edilmesi sözleşme özgürlüğü ilkesinin bir parçası olan sözleşmenin karşı tarafını seçme özgürlüğüne aykırı düşecektir ${ }^{78}$. Bu sebeple, ortaklık sözleşmesine konulan mirasçılarla devam kaydının mirasçılara yönelmiş bir öneri niteliğinde olduğu ileri sürülmüştür ${ }^{79}$. Mirasçılar mirası reddetme yoluna başvurmadıkları takdirde öneriyi kabul etmiş sayılacaklar ve böylelikle ölen ortağın ortaklık sıfatını kazanacaklardır ${ }^{80}$.

Kanaatimizce burada külli halefiyet ilkesinden ayrılmayı gerektirecek bir durum yoktur. Ortaklık sözleşmesine konulan ya da ayrı bir sözleşmeyle kararlaştırılan mirasçılarla devam kaydı öneri olarak nitelendirilemez. Zira öneri, bir tarafın karşı tarafi sözleşme yapmaya davet ettiği bir irade beyanıdır. Ortakların mirasçılarla devam kaydını koyarken sahip oldukları irade, mirasçılara ortaklık sözleşmesi yapmayı teklif etmek değildir. Buradaki irade, mirasçıların doğrudan doğruya ölen ortağın hukuki durumuna halef olmasına ve ortaklığın bu suretle devamına yönelmektedir. Dolayısıyla ortaklar arasında mirasçılarla devam kaydı söz konusu olduğu takdirde, ortağın ölümüyle birlikte onun mirasçıları kendiliğinden ortaklık sıfatını kazanacaklardır ${ }^{81}$. Ancak öğretide bir görüşe göre, adi ortaklığın mirasçılarla devamında külli

77 Wolf'e göre halefiyet klozları, mirasçıları ortaklığı devam ettirmeye zorlayan girişimlerdir. Bu bakımdan mirasçılara seçim hakkı tanıyan ortaklığa giriş klozlarından ayrılmaktadırlar. Bkz: Wolf, s. 91. Handschin'e göre, sözleşmede bulunan halefiyet klozu, ölen ortağın ortaklık sıfatını veraset yoluyla intikali mümkün (vererblich) hale getirir. Bu bakımdan mirasçıların ortaklığa girmeleri için herhangi bir irade beyanında bulunmaları gerekmez. Bkz: Handschin, Auflösung, s. 220.

78 Türkmen, s. 151.

79 Türkmen, s. 153.

80 Türkmen, s. 154.

81 Eren, Özel Hükümler, s. 885; Handschin/Vonzun, ZK-OR, Art. 545-547, N. 47-48; Handschin, Auflösung, s. 220. 
halefiyet ilkesinin katı bir biçimde uygulanması düşünülemez ${ }^{82}$. Mirasçılar, ortaklık sözleşmesindeki kayıt sebebiyle ortaklık sıfatını kazansalar da, ortaklıkta kalmaya zorlanamazlar. Başka bir deyişle, ortaklık sözleşmesindeki devam kaydı, mirasçılara adi ortaklıkta kalma borcu yüklemez ${ }^{83}$. Bu sebeple, adi ortaklıkta kalmak istemeyen mirasçının ortaklıktan çıkabileceğini kabul etmek gerekmektedir. Mirasçı, adi ortaklıktan çıkmak için diğer mirasçıların muvafakatini almak zorunda değildir ${ }^{84}$. Buna karşılık İsviçre öğretisinde savunulan bir görüş, ortak olmak istemeyen mirasçının ya mirası reddetmesi gerektiğini ya da mirasın resmi tasfiyesini istemek durumunda olduğunu ileri sürmektedir ${ }^{85}$. Resmi tasfiyenin talep edilmesi, beraberinde adi ortaklığın da tasfiye edilmesi sonucunu doğuracaktır ${ }^{86}$.

\section{Miras Ortaklığının Adi Ortaklığa Dâhil Olup Olamayacağı Meselesi}

Mirasçılarla devam kaydına ilişkin ikinci tartışma konusu, adi ortaklığa bir bütün olarak miras ortaklığının mı yoksa bireysel olarak mirasçıların mı ortak olduğu meselesidir. Öğretide bir görüş, bu durumda tüm mirasçıların ayrı ayrı adi ortaklığın ortağı haline geleceğini ileri sürmektedir ${ }^{87}$. Bu görüşe göre mirasçılar, miras payları oranında ölen ortağın ortaklıktaki hak ve borçlarına sahip olacaklardır ${ }^{88}$. Ancak ölen ortağın yönetim hakkı bu konuda istisna teşkil etmektedir. Hatta yönetim hakkının mirasçılara geçeceğine dair sözleşmede hüküm bulunsa bile, bunun diğer ortakları bağlamayacağı ifade edilmektedir ${ }^{89}$. Adi ortaklığa mirasçıların ayrı ayrı ortak olacaklarını ileri süren görüş, esasen Alman hukukunda ağırlık kazanmıştır ${ }^{90}$. Bu görüşün temsilcilerinin gerekçe olarak sundukları en temel husus, miras ortaklığının yapısıyla adi ortaklığın

82 Reha Poroy/Ünal Tekinalp/Ersin Çamoğlu, Ortaklıklar ve Kooperatif Hukuku, Vedat Kitapçılık, İstanbul, 2010, s. 80.

83 Poroy (Tekinalp/Çamoğlu), s. 80.

84 Poroy (Tekinalp/Çamoğlu), s. 80.

85 Handschin/Vonzun, ZK-OR, Art. 545-547, N. 56.

86 Handschin/Vonzun, ZK-OR, Art. 545-547, N. 56.

87 Domaniç, s. 426; Aykun, s. 37; Resul Narin, Adi Şirketin Sona Ermesi, Yayınlanmamış Yüksek Lisans Tezi, Ankara Üniversitesi Sosyal Bilimler Enstitüsü, 2010, s. 32.

88 Domaniç, s. 426; Aykun, a. 37; Narin, s. 32.

89 Domaniç, s. 426; Narin, s. 32.

90 Bkz: Peter Ulmer/Carsten Schäfer, Münchener Kommentar zum Bürgerlichen Gesetzbuch, 8. Auflage, C.H.Beck Verlag, 2021, § 727, N. 33. Ayrıca bkz. Türkmen, s. 139 vd; Handschin, Auflösung, s. 222. 
yapısının uyuşmamasıdır. Miras ortaklığı, hemen hemen her konuda oybirliği ilkesini zorunlu kıldığından dolayı ağır işleyen bir yapıya sahiptir. Böyle bir ortaklığın adi ortaklığa dâhil olması, ortaklığın devamı bakımından sakıncalı görülmektedir. Öte yandan İsviçre öğretisinde var olan bir görüş, farklı bir çözümle aynı sonuca varmaktadır ${ }^{91}$. Bu görüşe göre, miras ortaklığ1 tasfiye amaciyla kanun gereği kurulan geçici nitelikte bir ortaklıktır. Her bir mirasçının bu ortaklığın sona ermesini herhangi bir zamanda talep etme hakkı bulunmaktadır. Miras ortaklığının adi ortaklığa girmesi durumunda, adi ortaklık da herhangi bir zamanda feshedilme tehlikesiyle karşı karşıya kalacaktır. Bu nedenle, miras ortaklığının adi ortaklığa girdiği kabul edilemez. Birden fazla mirasçının bulunduğu hallerde, ölen ortağın payı bakımından miras ortaklığının bir adi ortaklığa dönüştüğü kabul edilmelidir. Böylelikle mirasçılar, adi ortaklık içerisinde bir alt ortaklık (Untergesellschaft) şeklinde var olmaya devam ederler ${ }^{92}$.

Öğretide yer alan karşıt görüş ise, mirasçılarla devam kaydı bulunan hallerde bir bütün olarak miras ortaklığının adi ortaklığa girdiğini savunmaktadır ${ }^{93}$. Bizim de katıldığımız bu görüşe göre, elbirliği ilkesinin gereği olarak ölen ortaktan intikal eden ortaklık sıfatı üzerinde bütün mirasçıların elbirliği halinde hak sahipliği söz konusudur ${ }^{94}$. Dolayısıyla mirasçılara bir bütün halinde intikal eden ortaklık sıfatının ve buna bağlı hakların, mirasçılar tarafından bağımsız olarak ayrı ayrı kullanılması söz konusu olamaz. Mirasçılar, ölen ortağın hukuki durumundan doğan tüm hak ve yükümlülüklerle birlikte bir miras ortaklığı olarak adi ortaklığa katılırlar ${ }^{95}$. Şu halde mirasçılar, miras ortaklığ halinde ölen ortakla aynı oy gücüne ve aynı kar-zarar payına sahip olacaklardır ${ }^{96}$.

Mirasçıların bir miras ortaklığı olarak adi ortaklığa girmeleri, ortaklığın işleyişi bakımından sorunlara meydan verebilir. Ancak sırf adi ortaklığın işleyişinin aksayacağ 1 gerekçesiyle miras ortaklığının temel nitelikleri görmezden gelinemez. Ölen ortaktan intikal eden ortaklık sıfatı bakımından

\footnotetext{
91 Wolf, s. 94.

92 Wolf, s. 94.

93 Poroy (Tekinalp/Çamoğlu), s. 81; Handschin/Vonzun, ZK-OR, Art. 545, N. 52; Handschin, Auflösung, s. 222.

94 Türkmen, s. 144 vd.

95 Handschin/Vonzun, ZK-OR, Art. 545, N. 52.

96 Handschin/Vonzun, ZK-OR, Art. 545, N. 53.
} 
mirasçılar arasında anlaşmazlık bulunuyorsa, mirasçılardan her birinin terekeye temsilci atanması için mahkemeye başvurma imkânı bulunmaktadır (TMK m. 640/3). Mahkeme tarafindan tereke temsilcisi atandığ mirasçıların elbirliği ile hak sahibi oldukları ortaklık sıfatı temsilci tarafından kullanılacaktır. İsviçre öğretisinde, mirasçıların adi ortaklığa miras ortaklığı şeklinde girmelerinin pratik sonuçlarının abartılmaması gerektiği ileri sürülmektedir ${ }^{97}$. Zira Alman Hukukunda olduğu gibi, mirasç1ların bireysel olarak adi ortaklığa girdikleri düşünülse bile, karar almak için oybirliğinin gerektiği durumlarda bir mirasçının karşı çıkması yine kararın alınamamasına yol açacaktır ${ }^{98}$.

\section{Mirasçılarla Devam Kaydında Şekil Sorunu}

Adi ortaklık sözleşmesinde ya da bundan bağımsız bir sözleşmede yer alan mirasçılarla devam kaydının şekli konusunda kanunda bir düzenleme bulunmamaktadır. $\mathrm{Bu}$ sebeple öğretide farklı görüşler ileri sürülmüştür. Bir görüşe göre, mirasçılarla devam kaydının şekle tabi olup olmadığı noktasında bu kaydın niteliğine göre bir ayrım yapılmalıdır. Eğer mirasçılarla devam kaydı, adi ortaklığın ölen ortağın bütün mirasçılarıyla devamını öngörüyorsa şekle tabi değildir ${ }^{99}$. Zira bu durumda mirasçılarla devam kaydının sağlararası bir işlemi konu edindiği kabul edilmektedir. Mirasçılarla devam kaydının yalnızca bir veya birkaç mirasçı ile ortaklığın devamını içerdiği durumlarda ise, bu kaydın mirasın kısmen paylaştırılması şeklinde yorumlanabileceği ifade edilmektedir ${ }^{100}$. Bu şekilde bir yorum, doğal olarak sözleşmedeki kaydın ölüme bağlı tasarruf kabul edilmesini ve böylelikle ölüme bağl1 tasarrufların tabi olduğu şeklin uygulanmasını gerektirmektedir ${ }^{101}$. İsviçre öğretisinde ileri sürülen bir görüş de, mirasçıları ortaklığı devam ettirmeye zorlayan kaydın ölüme bağlı tasarruf olarak nitelendirilmesi gerektiğini beyan etmektedir ${ }^{102}$. Söz konusu görüşe göre, bir mirasçıya ortaklığa girme yükümlülüğü ancak miras sözleşmesi yoluyla tesis edilebilir ${ }^{103}$.

\footnotetext{
97 Handschin/Vonzun, ZK-OR, Art. 545, N. 53.

98 Handschin/Vonzun, ZK-OR, Art. 545, N. 53.

99 Poroy (Tekinalp/Çamoğlu), s. 80.

100 Poroy (Tekinalp/Çamoğlu), s. 80.

101 Poroy (Tekinalp/Çamoğlu), s. 80; Handschin/Vonzun, ZK-OR, Art. 545, N. 63.

102 Wolf, s. 92.

103 Wolf, s. 92.
} 
Buna karşıl1k diğer bir görüş, kapsamı ne olursa olsun mirasçılarla devam kaydının tam üçüncü kişi lehine sözleşme niteliğinde olduğunu ve dolayısıyla ölüme bağlı tasarruflara ilişkin şekil şartlarına tabi olmadığını ileri sürmektedir ${ }^{104}$. Bu görüşe göre, mirasçılar sözleşmede yer alan üçüncü kişi lehine şart sebebiyle ortaklığa girmektedirler. Mirasçılarla devam kaydı, vasiyet benzeri bir ölüme bağlı kazandırma olarak kabul edilse dahi, bunun ölüme bağlı tasarrufların tabi olduğu şekilde yapılması zorunlu değildir.

Kanaatimizce her iki görüşün de sorunlu tarafları vardır. Her şeyden evvel, ortaklık sözleşmesinde yer alan bir veya birkaç mirasçı ile devam kaydının mirasın kısmen paylaştırılması şeklinde yorumlanması oldukça zordur. Zira bu yoruma başvurabilmek için ölen ortağın iradesinin mirasın kısmen paylaştırılması yönünde olduğunun şüpheye yer bırakmayacak ölçüde açık olması gerekir. Öte yandan, mirasçılarla devam kaydı ölen ortağın tek başına kararlaştırabileceği bir husus değildir. Bunun için diğer ortakların da rızası gerekmektedir. Diğer bir deyişle, bütün ortaklar sözleşmede böyle bir kaydın yer almasına rıza göstermeli ya da bu konuda ayrı bir sözleşme yapmalıdırlar. Ölen ortak, söz gelimi el yazılı vasiyetname düzenleyerek adi ortaklığın yalnızca bir mirasçı ile devam etmesini belirtmiş olsa, vasiyetnamedeki bu kaydın diğer ortakları bağlamayacağı açıktır.

Mirasçılarla devam kaydının ortaklık sözleşmesine konulmuş üçüncü kişi lehine bir kayıt olduğunu kabul etmek daha tutarlı görünmektedir. Ancak mirasçılarla devam kaydının üçüncü kişi lehine sözleşme kurumuna tam anlamıla oturduğu da söylenemez. Bilindiği üzere üçüncü kişi lehine sözleşmede borçlu (vaadeden), alacaklıya (vaadettiren) üçüncü kişi yararına taahhütte bulunmaktadır. Adi ortaklığın mirasçılarla devam kaydında ise, ölen ortak dışındaki ortakların mirasçılara bir edimde bulunmayı borçlanmaları söz konusu değildir. Başka bir ifadeyle, diğer ortaklar ölen ortağın mirasçılarıyla ortaklık sözleşmesi yapmayı taahhüt etmemektedirler. Mirasçılarla devam kaydı, ölen ortağın ortaklık sıfatının da mirasçılara geçerek ortaklığın ayakta kalmasına hizmet eden bir imkândır. Dolayısıyla ölen ortağın mirasçıları, diğer ortakların sözleşme yapma teklifi neticesinde değil, külli halefiyet ilkesinin neticesi olarak ortaklığa girmektedirler. Öte yandan, üçüncü kişi lehine sözleşmeler bakımından geçerli olan üçüncü kişi zararına sözleşme yasağı da, bu noktada tereddüt oluşturmaktadır. Mirasçıların ölen ortağın ortaklık sıfatını elde etmeleri, onlar bakımından yalnızca alacak hakkının kazanılması değil,

104 Şener, s. 446; Aksu, s. 42. 
aynı zamanda ortaklık ilişkisi sebebiyle borç altına sokulmaları anlamına gelmektedir. Gerçi öğretide, ortaklık konumuyla birlikte gelen borçların bu konumun beraberinde gelen haklar karşısında "hafif çekeceğini" ifade eden yazarlar vardir ${ }^{105}$. Ancak durum her zaman böyle olmayabilir.

Mirasçılarla devam kaydını adi ortaklık ilişkisinin devamını sağlayan kendine özgü (sui generis) nitelikte bir sözleşme olarak kabul etmek kanatimizce daha doğru olacaktır. Zira bu durum, ne ölüme bağlı tasarrufların ne de üçüncü kişi lehine sözleşmelerin yapısına tam anlamıyla uymamaktadır. Mirasçılarla devam kaydının kilit noktası, bu kaydın kendiliğinden ortaklık sıfatının mirasçılara intikalini sağlamasında ve böylelikle adi ortaklığ dağılmaktan (infisah etmekten) kurtarmasında karşımıza çıkmaktadır. Kendine özgü nitelikte sözleşmelere uygulanacak hukuk kuralları bakımından öncelikle tarafların iradelerine bakılır. Sözleşmenin tarafları özgün bir kural koymuşlarsa, bu kurala göre uyuşmazlığın çözümü yoluna gidilir. Ortaklar, mirasçılarla devam kaydını içeren sözleşmenin belirli bir şekilde yapılmasını kararlaştırmış olabilirler. Bu durumda mirasçılarla devam kaydının öngörülen şekilde yapılması zorunludur. Böyle bir kural söz konusu olmadığı takdirde, TBK'nun genel hükümleri uygulama alanı bulur. Şu halde, sözleşmeler için geçerli olan şekil serbestisi ilkesi burada da uygulanır ve mirasçılarla devam kaydının herhangi bir şekle tabi olmadığı sonucuna ulaşmak gerekir.

\section{B. Sözleşmede Sağ Kalan Ortaklarla Devam Kaydının Bulunması}

\section{Genel Olarak}

Ortaklardan birinin ölümü halinde adi ortakllğı kendiliğinden sona ermekten kurtaracak olan diğer bir durum, sözleşmede ortaklığın sağ kalan ortaklarla devamına ilişkin bir kaydın yer almasıdır (Fortsetzungsklausel) ${ }^{106}$. Özellikle ekonomik bakımdan güçlü yapıda olan adi ortaklıklar bakımından bu yolun tercih edilmesi söz konusu olabilir ${ }^{107}$. Zira să̆ kalan ortaklarla devam kayd yerine mirasçılarla devam kaydı tercih edilirse, sağ kalan ortaklar hiç tanımadıkları mirasçılarla muhatap olmak durumunda kalacaklardır.

\footnotetext{
105 Rona Serozan, Sağlararası İşlem Yoluyla Ölüme Bağlı Kazandırma, 1. Bası, İstanbul, 1979, s. 159.

106 Wolf, s. 83; Christ, SHK-OR, Art. 545, N. 14; Müller, OFK-OR, Art. 545, N. 4; Handschin/ Vonzun, ZK-OR, Art. 545, N. 65; Handschin, Auflösung, s. 224; Jung, CHK-OR, Art. 545546, N. 4; Jung, Regelung, s. 177; Truniger, Präjudizienbuch OR, Art. 545, N. 4; Eren, Özel Hükümler, s. 885.

107 Türkmen, s. 160.
} 
Să̆ kalan ortaklarla devam kayd, herhangi bir şekle tabi değildir ${ }^{108}$. Isviçre Federal Mahkemesine göre, ortaklığın malvarlığında taşınmazlar bulunsa bile, săg kalan ortaklarla devam kaydı bakımından şekil zorunluluğu yoktur ${ }^{109}$. Ancak ispat kolaylı̆̆ bakımından, ortaklardan birinin ölümü halinde ortaklı̆̆ın să̆ kalan ortaklarla devam edeceğinin yazılı olarak kayıt altına alınması tavsiye edilebilir ${ }^{110}$.

Sağ kalan ortaklarla devam kaydının somut anlamı, ölen ortağın ölüm anından itibaren kendiliğinden ortaklıktan çıkmasıdır. Bu durumun iki temel sonucu vardır. Birincisi, ölen ortağın ortaklık malvarlığındaki payının sağ kalan ortaklara geçmesidir ${ }^{111}$. İkincisi ise, ölen ortağın mirasçılarının sağ kalan ortaklara karşı ölen ortağa ait olan ayrılma payını talep hakkının doğmasıdır.

\section{2. Ölen Ortağın Ortaklık Payının Sağ Kalan Ortaklara Geçmesi}

Türk Borçlar Kanunu m. 634/1 hükmüne göre, adi ortaklıkta bir ortağın ortaklıktan çıkması veya çıkarılması durumunda payı, diğer ortaklara payları oranında kendiliğinden geçmektedir ${ }^{112}$. Belirtmek gerekir ki, söz konusu hükümde ifade edilen "pay", esasen ortakların ortaklık malvarlığı üzerindeki paylarıdır ${ }^{113}$. Adi ortaklığın, kendisini oluşturanlardan bağımsız bir hak süjesi karakteri bulunmamaktadır ${ }^{114}$. Bunun sonucu olarak, ortaklık malvarlığ 1 üzerinde bütün ortaklar elbirliğiyle hak sahibidirler. İște TBK m. 634/1 hükmü bakımından çıkan ortağın payının diğer ortaklara geçmesi, esasen çıkan ortağın ortaklık malvarlığı üzerindeki haklarının sona ermesi anlamına gelmektedir. Başka bir deyişle, çıkan ortak ile ortaklık malvarlığı arasındaki hukuki bağ ortadan kalkmış olmaktadır ${ }^{115}$.

Ölen ortağın ortaklık malvarlığı üzerindeki payının sağ kalan ortaklara kendiliğinden geçmesi, ortaklık malvarlığı üzerindeki mülkiyet durumunun da değişmesi sonucunu doğurur. Sağ kalan ortakların ortaklık malvarlı̆̆1

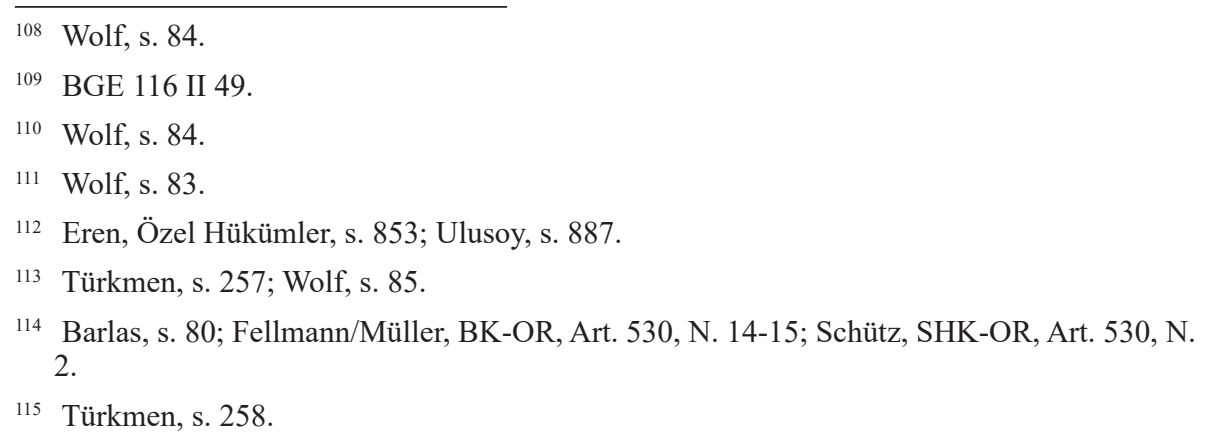


bakımından sahip oldukları hukuki durumlarında bir genişleme meydana gelir. Mesele özellikle taşınmazlar bakımından önem kazanmaktadır. Adi ortaklığın malvarlığına dâhil olan taşınmaz tapu sicilinde adi ortaklık adına değil, bütün ortaklar adına tescil edilebilir ${ }^{116}$. Zira adi ortaklığın tüzel kişiliği yoktur. Şu halde sağ kalan ortaklarla devam kaydı var olduğu takdirde, ölen ortağın söz konusu taşınmaz üzerindeki mülkiyet hakkı kendiliğinden sona erer. Artık bu taşınmaz üzerinde yalnızca sağ kalan ortaklar elbirliği halinde maliktirler. Ancak maddi bakımdan gerçekleşen bu sonucun tapu siciline de yansıtılması gerekmektedir. Ölen ortağın mirasçıları, tapuda ferağ verdikleri takdirde gerçek durum tapu siciline yansıtılmış olur. Ancak mirasçıların buna yanaşmamaları durumunda, sağ kalan ortakların tapu sicilinin düzeltilmesini mahkemeden talep etmeleri gerekecektir.

\section{Mirasçıların Ayrılma Payını Talep Hakkı}

Sağ kalan ortaklarla devam kaydının bulunduğu hallerde, mirasçılar ölen ortağın ortaklık sıfatını iktisap edemezler. Bununla birlikte, ölen ortağın ayrılma payının hesaplanarak mirasçılara ödenmesi gerekmektedir. Zira ölen ortağın ayrılma payı, onun terekesinin aktifinde yer alan bir unsur olarak mirasçılara intikal etmektedir. Dolayısıyla mirasçılar, ölen ortağın ayrılma payı bakımından sağ kalan ortaklara karşı borçlar hukuku temelli bir alacak hakkına sahip olmaktadırlar (Abfindungsanspruch) ${ }^{117}$. Aynı durum, nitelikli devam kaydının bulunduğu hallerde de geçerlidir. Mirasçılardan biri veya birkaçı, nitelikli devam kaydı sebebiyle adi ortakllğın dışında bırakılmışsa, ölen ortağın ayrılma payının söz konusu mirasçılara düşen kısmının ödenmesi gerekecektir.

Ortaklıktan çıkma, bir anlamda çıkan ortak açısından tasfiye işlevine sahiptir. Nitekim TBK m. 634 hükmünün kenar başlı̆̆ "Ortaklık payının tasfiyesi" şeklindedir ${ }^{118}$. Burada, ortaklığın tamamen tasfiyesine benzeyen bazı işlemler sonucunda çıkan ortağın payı hesaplanmaktadır.

Ayrılma payı, esasen ortaklık sıfatını kaybeden ortağa, diğer ortaklar tarafindan bu kaybın telafisi amacıyla ödenen bir miktar paradır ${ }^{119}$. Bu bakımdan

\footnotetext{
116 Bornhauser, s. 651.

117 Handschin/Vonzun, Art. 545, N. 66; Handschin, Auflösung, s. 224; Wolf, s. 85.

118 Ulusoy, s. 887.

119 Ulusoy, s. 888.
} 
ayrılma payının telafi edici/denkleştirici nitelikte olduğu ifade edilmektedir ${ }^{120}$. Ayrılma payının bir para alacağı olması sebebiyle, ölen ortağın mirasçılarına ortaklık malvarlı̆̆ 1 üzerindeki mülkiyet haklarının devri söz konusu değildir. Zira burada ayni nitelikte değil, sağ kalan ortakları borçlandırıcı nitelikte bir talep hakkı meydana gelmektedir. Hal böyle olmakla birlikte, sağ kalan ortaklarla mirasçıların anlaşmaları durumunda, ayrılma payının ayni olarak ödenmesine de bir engel bulunmamaktadır.

Ölen ortağın mirasçıları, ayrılma payının hesaplanarak kendilerine ödenmesini diğer ortaklardan talep edeceklerdir. Sağ kalan ortaklar, ölen ortağın ayrılma payının ödenmesi yönünden birinci dereceden, sınırsız ve müteselsilen sorumludurlar ${ }^{121}$. Şu halde mirasçılar ayrılma payını bütün ortaklardan talep edebilecekleri gibi, sadece birinden ya da birkaçından da talep edebilirler. Öte yandan, mirasçıların ayrılma payı alacağını talep ederken birlikte hareket etmeleri gerekmektedir. Ayrılma payı, terekede yer alan bir alacak hakkı olduğundan, bunun talep edilmesi ancak bütün mirasçıların katılmaları ya da muvafakat etmeleri suretiyle olur.

Ayrılma payı alacağı, ortağın adi ortaklıktan ayrıldığı anda doğar. Ölen ortak bakımından ayrılma anı ölüm anıdır. Diğer bir ifadeyle, ölüm olayının gerçekleşmesiyle birlikte, ölen ortakla adi ortaklık arasındaki hukuki bağ ortadan kalkar. Böylece ölen ortak bakımından ayrılma payı alacağı doğmuş olur. Yine ölüm anıyla birlikte bu alacak, diğer tüm haklar ve borçlar gibi, ölen ortağın mirasçılarına intikal eder. Ayrılma payı alacağı, ölüm anında doğmakla birlikte bu anda muaccel olduğu söylenemez. Zira ayrılma payının tespit edilebilmesi için öncelikle ayrılma bilançosunun düzenlenmesi gerekmektedir. Dolayısıyla, ayrılma payı alacağının miktarı, ortağın ölümü anında belirli değildir. Bu sebeple, ayrılma payının hesaplanarak belirli hale geldiği anda muaccel olduğunu kabul etmek gerekmektedir ${ }^{122}$.

Ayrılma payının tespiti bakımından öncelikle sözleşmede bu konuda bir hüküm olup olmadığına bakılmalıdır. Eğer ortaklık sözleşmesinde ayrılma

120 Türkmen, s. 269.

121 Handschin/Vonzun, Art. 545, N. 72; Türkmen, s. 288. Aksi görüşte: Ulusoy, s. 889. Yazara göre, diğer ortakların çıkan ortağın tasfiye payını ödeme yükümlülükleri sınırsız ve müteselsil bir borç ilişkisinden doğmaz. Bunun iki sebebi vardır. İlk olarak, diğer ortaklar çıkan ortağın payına kendi payları oranında sahip olduklarına göre, tasfiye payının ödenmesinden de kendi payları oranında sorumlu olmalıdırlar. İkinci olarak ise, tasfiye payının ödenmesi borcu adi ortaklığın değil, diğer ortakların edindikleri payların karşılığı olarak kişisel borçlarıdır.

122 Türkmen, s. 293. 
payının ödenmesiyle ilgili düzenlemeye gidilmişse (Abfindungsklausel), buna göre hesap yapılır ${ }^{123}$. Ortaklık sözleşmesinde hüküm olmamakla birlikte, sonradan sağ kalan ortaklarla mirasçıların bu konuda anlaşmaları da söz konusu olabilir. Ancak ortaklık sözleşmesinde bir hüküm bulunmadığı ya da anlaşma sağlanamadığ takdirde TBK m. 634/3 hükmü devreye girmektedir. Söz konusu hükme göre, çıkan ortağın tasfiye payı, ortaklık sıfatının sona erdiği tarih itibarıyla mali işlerde uzman bir kişiye hesaplattırılacaktır ${ }^{124}$. Öğretide mali işlerde uzman kişiden kastın serbest muhasebeci veya mali müşavir olduğu belirtilmektedir ${ }^{125}$. Sağ kalan ortaklarla mirasçıların uzman kişi üzerinde anlaşmaya varamamaları durumunda, ayrılma payını belirleyecek olan uzman kişi hâkim tarafından atanacaktır (TBK m. 634/3).

Bilançonun ve devamında ayrılma payının tespit edilmesinden sonra, bu payın ölen ortağın mirasçılarına ödenmesi gündeme gelir. Ayrılma payı kural olarak nakden ve peşinen ödenmelidir ${ }^{126}$. Ancak sağ kalan ortaklarla ölen ortağın mirasçıların bu konuda anlaşmaları mümkündür. Örneğin ayrılma payının peşinen değil de taksitler halinde ödenmesi kararlaştırılabilir. Ayrılma payı muaccel olduğu halde ifa edilmezse, mirasçılar bunun ödenmesi için diğer ortaklara karşı alacak davası açabilirler. Ayrılma payı alacağı, on yıllık genel zamanaşımı süresine tabidir ${ }^{127}$. Zamanaşımı konusunda TBK $\mathrm{m}$. 147/1,b.4 hükmünün uygulanması düşünülebilir. Bahsi geçen hükme göre, bir ortaklıkta ortaklık sözleşmesinden doğan ve ortakların birbirleri veya kendileri ile ortaklık arasındaki alacaklar için beş yıllık zamanaşımı uygulanır. Ancak ayrılma payı alacağı, ortaklık ilişkisi sebebiyle doğan bir alacak değildir. Zira ayrılma ile birlikte ayrılan ortağın ortaklık sıfatı ortadan kalkmaktadır. Bu bakımdan ölüm sebebiyle ayrılan ortağın üçüncü kişi gibi kabul edilmesi söz

123 Handschin/Vonzun, Art. 545, N. 68. Wolf'e göre, sözleşmede ayrılma payına ilişkin konulan hükümde, mirasçıların ölen ortağın hayatta iken ortaklığ 1 terk edeceği duruma nazaran daha ağır bir durumla karşı karşıya kalmaları söz konusu ise, ölüme bağlı tasarruf şeklinde yapılması gerkmektedir. Yazar, şüpheli durumlardan kaçınabilmek adına, ölüme bağlı tasarruf şekillerine uyularak sözleşme yapılmasını tavsiye etmektedir. Bkz: Wolf, s. 85 .

124 Eren, Özel Hükümler, s. 853; Ulusoy, s. 888.

125 Türkmen, s. 298. Yazar, ayrılma payının tespiti için serbest muhasebeci veya mali müşavirin yanında işletme iktisadı konusunda uzman olan bir kişinin daha görevlendirilmesi gerektiği kanaatindedir. Zira yazara göre, serbest muhasebeci veya mali müşavir ayrılma bilançosunun düzenlenmesinde yetkilidir. Ayrılma payına değer biçilmesi ise işletme iktisadı alanına girmektedir.

126 Türkmen, s. 303.

127 Türkmen, s. 308. 
konusudur. Dolayısıyla ayrılma payı alacağ1, ortaklığın üçüncü kişiye karş1 yüklendiği bir borç niteliğindedir.

Ayrılma bilançosunun düzenlenmesi neticesinde, ölen ortağın lehine bir ayrılma payı alacağının doğmaması da ihtimal dâhilindedir. TBK m. 635 hükmüne göre, ortaklık sıfatının sona erdiği tarihte ortaklığın malvarlığının borçlarını karşılamaya yetmemesi durumunda, çıkan ortağın payına düşen borç tutarını diğer ortaklara ödemesi gerekmektedir ${ }^{128}$. Şu halde, ortaklığın borca batık olması ihtimalinde, ölen ortağın ayrılma payı alacağı değil, zarara katılma borcu gündeme gelecektir. Ayrılma payı alacağında olduğu gibi, ölen ortağın zarara katılma borcu da mirasçılara intikal eder. Dolayısıyla söz konusu borç, terekenin pasifinde yer alacak ve bu sefer, diğer ortaklar tarafından mirasçılardan talep edilebilecektir.

Kanunda, ayrılan ortağın payına düşen borç tutarının zarara katılmaya ilişkin düzenlemeler çerçevesinde ödeneceği belirtilmiştir (TBK m. 635). Burada kastedilen düzenleme TBK m. 623 hükmüdür. Kural olarak her ortağın zarardaki payı, katılma payının değerine ve niteliğine bakılmaksızın eşittir ${ }^{129}$. Ancak ortaklık sözleşmesinde zarara katılma bakımından farklı bir düzenleme yapılmış olabilir. Bu durumda ortaklık sözleşmesindeki hüküm uygulanacaktır.

Ölen ortağın mirasçıları, ortaklığın zararına katılma borcu bakımından müteselsilen sorumludurlar. Zira söz konusu borç, tereke borcu niteliğindedir. Sağ kalan ortaklar, borcun tamamı için bütün mirasçılara, içlerinden birine ya da birkaçına başvurabilirler. Eğer mirasçılardan biri kendi payına düşen miktardan fazlasını ödemek durumunda kalırsa, diğer mirasçılara rücu hakkına sahiptir.

\section{Ayrılma Payının Sözleşmeyle Kaldırılması}

Ortaklık sözleşmesinde ya da bundan bağımsız olarak ayrılma payının kaldırılması kararlaştıııldığı takdirde, böyle bir kaydın geçerli olup olmayacağ tartışmalıdır. Öğretide bir görüş, ayrılma payının sözleşme ile kaldırılabileceği kanaatindedir ${ }^{130}$. Bu görüşe göre, ayrılan ortağın sözleşme ile ayrılma

128 Eren, Özel Hükümler, s. 853.

129 Fellmann/Müller, BK-OR, Art. 533, N. 9; Handschin/Vonzun, ZK-OR, Art. 533, N. 41; Müller, OFK-OR, Art. 533, N. 3; Jung, CHK-OR, Art. 533, N. 2; Herren, SHK-OR, Art. 533, N. 31 .

130 Bollmann, s. 83 (Türkmen, s. 308'den naklen). 
payından feragat etmesi bir tür ibra sözleşmesidir. Başka bir deyişle ayrılan ortak, ayrıldığı takdirde doğacak olan ayrılma payı alacağı için diğer ortakları ibra etmiş olmaktadır. Buna karşılık, ayrılma payının kaldırılmasına yönelik sözleşmelere cevaz verilmemesini savunan bir görüş de bulunmaktadır ${ }^{131}$. Zira ortaklık sıfatını yitiren kişinin sahip olduğu en temel mali hak ayrılma payıdır ve bunun kaldırılması, ortaklıktan ayrılmanın cezalandırılması olarak yorumlanabilir ${ }^{132}$.

Kanaatimizce meseleye ekonomik özgürlügün sınırlandırılmas1 yönünden de bakılabilir. Ekonomik özgürlük, kişiliğin vazgeçilmez parçalarından birini teşkil etmektedir. Bu özgürlüğün önemli taraflarından biri ise, ekonomik faaliyette bulunma özgürlügüdür. Kişinin ekonomik faaliyette bulunma özgürlügünü aşırı derecede sınırlayan ve böylelikle onu ekonomik bakımdan bağımlı hale getiren sözleşmeler, kelepçeleme sözleşmeleri olarak adlandırılmaktadır ${ }^{133}$. Kelepçeleme sözleşmeleri, ahlaka aykırılık teşkil etmesi sebebiyle kesin hükümsüzdür. Eğer ayrılan ortağa ayrılma payı ödenmeyeceğine ilişkin kayıt, kelepçeleme sözleşmesi niteliğindeyse, ölen ortağın mirasçıları bunun kesin hükümsüz olduğunu ileri sürerek ayrılma payının ifasını talep edebilirler. Bu noktada, ölen ortağın sağlığında yaptığı sözleşmeden doğan borç ilişkisinin mirasçılara intikal etmemesi tereddüte sebep olabilir. Gerçekten de, mirasbırakanın kişisel özellikleri çerçevesinde taraf olduğu borç ilişkileri mirasçılara geçmemektedir. Hal böyle olmakla birlikte, ölen ortağın taraf olduğu sözleşmenin kesin hükümsüzlüğü, onun bu durumu ileri sürmesinden bağımsız olarak kendiliğinden var olan bir durumdur. Diğer ifadeyle, sözleşmenin ahlaka aykırılığı sebebiyle kesin hükümsüz olması, ölen ortağın sağlığında bunu ileri sürmesine bağlı değildir. Şu halde, ölen ortağın ayrılma payından mahrum kalacağına dair sözleşme kesin hükümsüz ise, ölen ortak lehine ayrılma payı alacağı doğmuş ve mirasçılara intikal etmiş demektir. Dolayısıyla, mirasçıların bu alacağı talep edebileceklerini kabul etmek gerekir.

Sağ kalan ortaklarla devam kaydının yanında, ölen ortağın ayrılma payının ortaklıkta kalmasına yönelik bir hüküm de sözleşmede öngörülmüş olabilir. Böylelikle, ortağın ölümü halinde onun ayrılma payı terekeye dâhil olmayacak ve mirasçıları tarafindan sağ kalan ortaklardan talep

\footnotetext{
131 Şener, s. 394; Türkmen, s. 309.

132 Şener, s. 394.

133 Akın Ünal, Kelepçeleme Sözleşmeleri, 2. Baskı, Adalet Yayınevi, Ankara, 2017, s. 125 vd.
} 
edilemeyecektir. Burada salt ölüm halinde ortaklıktan çıkmaya özgü bir durum düzenlenmiş olmaktadır. Ölüm halinde ortaklıktan çıkan ortağın ayrılma payının mirasçılara geçmesini engelleyen bu tür kayıtlar, genel olarak miras hukuku bakımından sakıncalı görülmektedir ${ }^{134}$. Zira bu durum, mirasçıların ölen ortağın ayrılma payından mahrum edilmeleri sonucunu doğurmaktadır. Mutlak nitelikte ortaklık ilişkisine dayalı bir hak olan ayrılma payının, her durumda mirasçılara ödenmesi gerektiği ifade edilmektedir ${ }^{135}$. İsviçre hukukunda ileri sürülen bir görüşe göre ise, ölüm durumunda ortağın ayrılma payının ortaklıkta kalacağına dair kayıt, esasen bir ölüme bağlı tasarruf niteliğindedir ${ }^{136}$. Bu sebeple, söz konusu kayıt ölüme bağl1 tasarruflar için aranan şekil şartlarını taşıdığı takdirde mirasçılar bakımından bağlayıcı kabul edilebilir.

\section{5. İki Kişilik Adi Ortaklığın Durumu}

İki kişiden oluşan bir adi ortaklığın varlığı halinde de sözleşmeye sağ kalan ortakla devam kaydı konulması mümkündür. Ancak bu ihtimalde söz konusu kayıt doğal olarak ortaklığın sona ermesini engellemeyecektir ${ }^{137}$. İki ortaktan birinin ölmesiyle birlikte, ölen ortağın payı kendiliğinden (eo ipso) diğer ortağa geçecek ve böylelikle sağ kalan ortak, önceden elbirliği halinde malik olduğu ortaklık malvarlığı üzerinde artık tek başına malik olacaktır ${ }^{138}$. $\mathrm{Bu}$ durumda ortaklığın malvarlığının tasfiye edilmesine gerek kalmaz. Ölen ortağın mirasçıları, onun ayrılma payını sağ kalan ortaktan talep edebilirler.

\section{Sözleşmede Ortaklığa Giriş Kaydının Bulunması}

Mirasçılarla devam kaydı bulunan hallerde, ortağın ölümüyle birlikte onun mirasçıları doğrudan ortaklık sıfatını da elde etmiş olurlar. Bu bakımdan ölen ortağın mirasçılarının herhangi bir müdahalesi söz konusu değildir. Ortaklık sıfatı, külli halefiyet ilkesi gereğince kendiliğinden intikal eder.

134 Türkmen, s. 339. Yazar, özellikle Alman hukuku bakımından konunun tartışıldığını, görüş birliği olmamakla beraber, ortaklığın sağ kalan ortaklarla devamının kararlaştırıldığı durumlarda ayrılma payının kaldırılmasına cevaz verildiğini ifade etmektedir.

135 Türkmen, s. 340.

136 Handschin/Vonzun, Art. 545, N. 69.

137 Wolf, s. 85.

138 Wolf, s. 85. Ancak ortaklık malvarlığı içerisinde tapuya kayıtlı taşınmazlar varsa, ölen ortağın mirasçılarının sağ kalan ortak lehine tapuda ferağ vermeleri gerekmektedir. Aksi takdirde sağ kalan ortak, ortaklık malvarlığında bulunan taşınmaz üzerinde tek başına malik olarak gözükmeyecektir. 
Ancak ortaklar, adi ortaklığın mirasçılarla devamı yönünden ölen ortağın mirasçılarına bir seçme hakkı tanımak isteyebilirler. Öğretide "giriş klozu (Eintrittsklausel) ${ }^{139}$ " olarak da adlandirllan bu kayıt sayesinde, ölen ortağın mirasçılarına ortaklı̆̆a devam etme noktasında bir tercih imkânı verilmiş olmaktadır.

Ortaklı̆̆a giriş kaydl, mirasçılarla devam kaydı ile săg kalan ortaklarla devam kaydının etkilerini birleştiren bir özelliğe sahiptir ${ }^{140}$. Bu kayıt ile mirasçı, adi ortaklı̆ga girerek ortaklık sıfatını kazanmak veya ortaklığa girmeyerek ölen ortağın ayrılma payını talep etmek arasında bir seçim hakkına (Optionsrecht) sahip olmaktadır. Ortaklığa giriş hakkı, sözleşme ile mirasçılardan birine veya birkaçına da tanınabilir (qualifizierte Eintrittsklausel) ${ }^{141}$.

Ortaklığa giriş kaydl, sağlararası bir hukuki işlem olarak herhangi bir şekil şartına, özellikle de ölüme bağll tasarruflar için öngörülen şartlara tabi değildir ${ }^{142}$. Hal böyle olmakla birlikte, özellikle bir veya birkaç mirasçı lehine giriş kaydının bulunduğu hallerde, mirasbırakanın diğer mirasçıları göz ardı etmemek adına bir ölüme bağlı tasarruf ile paylaşma kuralı öngörmesi faydalı olacaktır $^{143}$.

Mirasçılar tarafindan seçim hakkının kullanılmasına kadar, mirasçıların durumu askıdadır. Bu aşamada mirasçılar ortak sıfatına sahip değildirler. Dolaylsıyla ortaklığın karar alma sürecine katılmaları da söz konusu değildir ${ }^{144}$. Mirasçıların ortak sıfatını kazanabilmeleri için, ortaklığa girmeye yönelik iradelerini açıklamaları (Eintrittserklärung) gerekmektedir. Şu halde, sözleşmede mirasçılara ortaklığa giriş hakkı tanıyan kayıt bir tür öneri iken, mirasçıların buna olumlu yönde cevap vermeleri kabul niteliğindedir ${ }^{145}$.

Mirasçılar, dürüstlük kuralının bir gereği olarak makul bir süre içerisinde

139 Türkmen, s. 164; Handschin/Vonzun, Art. 545, N. 73; Christ, SHK-OR, Art. 545, N. 13; Jung, CHK-OR, Art. 545-546, N. 4; Jung, Regelungen, s. 179; Wolf, s. 87; Handschin, Auflösung, s. 225.

140 Handschin/Vonzun, Art. 545, N. 73; Handschin, Auflösung, s. 225.

141 Wolf, s. 88; Handschin/Vonzun, Art. 545, N. 73; Handschin, Auflösung, s. 225.

142 Wolf, s. 88.

143 Wolf, s. 90.

144 Handschin/Vonzun, Art. 545, N. 74; Handschin, Auflösung, s. 225.

145 Türkmen, s. 165. Ortaklık sözleşmesinde bulunan giriş kaydının yalnızca bir teklif olup, mirasçılara yükümlülük getirmediği yönünde bkz: Wolf, s. 90. 
seçim hakkını kullanmalıdır ${ }^{146}$. Öğretide, mirasçıların seçim hakkını kullanmaları noktasında ortaklık sözleşmesine koyulan giriş kaydıyla belirli bir süre öngörülebileceği ifade edilmektedir ${ }^{147}$. Mirasçılar, sözleşmede gösterilen sürede ya da makul bir süre içerisinde seçim hakkını kullanmadıkları takdirde, ortaklık mevcut ortaklarla devam eder. Bu durumda mirasçılar, sanki sağ kalan ortaklarla devam kaydı varmış gibi, ölen ortağın ayrılma payını talep edebileceklerdir ${ }^{148}$.

\section{Sözleşmede Herhangi Bir Devam Kaydının Bulunmaması}

Ortaklık sözleşmesinde ortaklardan birinin ölümü halinde ortaklığın akıbetinin ne olacağına dair herhangi bir hükmün yer almaması ihtimal dâhilindedir. Aynı şekilde, ortaklığın devamı sırasında da bu husus hiç gündeme gelmemiş ve ortaklık sözleşmesinden ayrı bir sözleşmeye de konu edilmemiş olabilir. $\mathrm{Bu}$ durumda kural olarak ortaklardan birinin ölümüyle birlikte adi ortaklık sona ermiş sayılacaktır. Fakat daha önce de değinildiği gibi ortaklığın sona ermesi, ortaklık ilişkisinin bir anda ortadan kalkması sonucunu doğurmamaktadır. Burada esasen ortaklığın tasfiye sürecine girmesi söz konusudur. İşte bu tasfiye sürecine girilmeden önce, sağ kalan ortaklarla ölen ortağın mirasçılarının, ortaklığın devamı hususunda anlaşmaya varmaları mümkündür ${ }^{149}$.

Kanunda, adi ortaklık bakımından ortaklardan birinin ölümü halinde sağ kalan ortaklarla mirasçıların anlaşarak ortaklığı devam ettirebileceklerine dair açık bir hüküm bulunmamaktadır. Öğretide ise, sağ kalan ortaklarla mirasçıların oybirliği ile alacakları kararla ortaklığın devamının mümkün

146 Türkmen, s. 165.

147 Handschin/Vonzun, Art. 545, N. 77.

148 Handschin/Vonzun, Art. 545, N. 79.

149 Müller, OFK-OR, Art. 545, N. 4; Handschin/Vonzun, ZK-OR, Art. 545, N. 47. "Dava, adi ortaklĭgın fesih ve tasfiyesine ilişkin olup, firın işletmeciliği ile ilgili adi ortaklığın davacı ile davalı arasında değil, davacının murisi Selma ile davalı arasında kurulduğu mahkemece uyulan bozma ilamında açıça belirtilmiştir. Hemen belirtmek gerekir ki, BK'nın 535. hükmü gereğince, taraflar arasında başkaca bir kararlaştırma yoksa adi ortaklık ölüm ile son bulur. Davacının murisi Selma 17.08.1999 tarihinde meydana gelen deprem sonucu öldügüne göre, adi ortaklık bu tarihte sona ermiştir. Mahkemenin de kabulünde olduğu gibi, murisin ölümünden sonra adi ortakliğın taraflar arasında sürdüğ̈̈ de kanıtlanamamıştır. Eldeki dava, muris Selma ile davalı arasındaki adi ortaklı̆̆ın fesih ve tasfiyesi olduğuna ve Selma'nın da 17.08.1999 tarihinde öldüğünün anlaşılmasına göre, fesih ve tasfiyenin bu tarih itibariyle yapılması zorunludur". Yarg. 13. HD, E. 2008/404, K. 2008/10164, T. 17.7.2008. 
olduğu, hatta sağ kalan ortaklarla bazı mirasçılar arasında dahi ortaklığa devam edilebileceği kabul edilmektedir ${ }^{150}$. Sağ kalan ortaklarla mirasçılar arasında ortaklığın devamına ilişkin yapılacak olan sözleşme herhangi bir şekle tabi değildir ${ }^{151}$. Ancak burada açık ya da örtülü şekilde ortaklığın devamına karar verildiği anlaşılabilmelidir ${ }^{152}$. Örneğin sağ kalan ortaklar ile mirasçılar, ortaklığın işlerini yürütmeye devam ediyorlarsa, bunlar arasında ortaklığın devamına dair örtülü şekilde yapılmış bir sözleşmenin var olduğu düşünülebilir ${ }^{153}$.

Diğer yandan, sağ kalan ortaklar ile mirasçıların ortaklığın yalnızca sağ kalan ortaklarla devamı yönünde karar almaları da mümkündür ${ }^{154}$. Ancak bunun için doğal olarak, sağ kalan ortak sayısının birden fazla olması gerekmektedir. Zira ölen ortak dışında yalnızca bir ortağın bulunması halinde, ortaklığın sağ kalan ortakla devamı mümkün değildir.

Sağ kalan ortakların kendi aralarında anlaşarak mirasçılar olmaksızın ortaklığın devamına karar verip veremeyecekleri tartışmalıdır. Bazı yazarlar bu duruma cevaz vermektedirler ${ }^{155}$. Ancak sağ kalan ortakların bu konuda karar veremeyeceklerini ifade eden bir görüş de bulunmaktadır ${ }^{156}$. Kanaatimizce, sağ kalan ortakların mirasçılardan bağımsız olarak ortaklığı kendi aralarında sürdürebilmelerine olumlu bakmak gerekir. Zira aksi yöndeki kabul, ortaklığı devam ettirme iradesine sahip olan ortaklar bakımından sürecin zorlaştırılmasından başka bir şey ifade etmemektedir. Bunun yerine, ölen ortağın mirasçılarına ayrılma payının ödenerek ortaklığın sağ kalan ortaklarla

150 Şener, s. 448; Poroy (Tekinalp/Çamoğlu), s. 81; Aykun, s. 40.

151 Poroy (Tekinalp/Çamoğlu), s. 81; Müller, OFK-OR, Art. 545, N. 4. Federal Mahkeme de vermiş olduğu bir kararda, gerek ortaklık sözleşmesinde bulunan devam kaydının gerekse de sonradan ortaklığın devamına ilişkin yapılacak sözleşmenin herhangi bir şekle tabi olmadığını ifade etmiştir. Bkz: BGE 116 II 49.

152 Aksu, s. 45.

153 "Somut olayda, davacıların murisi Yılmaz ile kardeși olan davalı arasında 28/12/2008 tarihinde, 5 yll süreli, uğraş konusu ....Yă Sanayi olan, kar ve zararın \%50- \%50 belirlendiği yazılı ortaklık sözleșmesi mevcuttur. Davacıların murisi Yılmaz, ortaklık sözleşmesinde belirlenen 5 ylllı süre dolmadan 16/11/2010 tarihinde ölmüştür. Sözleşmede, ölüm halinde ortaklığın devam edeceğine ilişsin hüküm bulunmadı̆̆ gibi, miraşşılarlyla da devam etmediği, davalının tek başına idare ettiği anlaşılmaktadır". Yarg. 3. HD, E. 2015/6226, K. 2015/12428, T. 3.7.2015.

154 Şener, s. 448; Narin, s. 36.

155 Yaşar Karayalçın, Ticaret Hukuku II, Şirketler Hukuku, 2. Bası, Ankara, 1973, s. 154.

156 Soysal Özenli, Uygulamada Adi Ortaklık ve Neden Olduğu Davalar, 1. Bası, Ankara, 1988, s. 118 . 
devamı yoluna gitmek çok daha pratik bir çözüm olacaktır. Ayrıca, sözleşmede mirasçılarla devam kaydı bulunmayan hallerde ölen ortağın ortaklık sıfatının mirasçılara intikal etmediğini de unutmamak gerekir. Mirasçıların bu ihtimallerdeki hakları, esasen ölen ortağın malvarlıksal durumunun halefi olarak, onun ayrılma payını talep etmekten ibarettir. Şu halde, mirasçılardan bazılarının ortaklığa devam etmeyi kabul etmemeleri durumunda da ortaklığın kabul eden mirasçılarla devam edebileceğini söylemek gerekir. Böylelikle, sağ kalan ortaklarla bazı mirasçılar ortaklığa devam ederler. Ortaklığa dâhil olmak istemeyen mirasçılara ise, kendi payları oranında ayrılma payının ödenmesi söz konusu olur ${ }^{157}$.

Adi ortaklık ister sağ kalan ortaklarla, isterse de sağ kalan ortaklar ve mirasçılarla devam etsin, her iki durumda da ortaklığın devamı yönündeki iradenin varlı̆̆ ortaklığın kendiliğinden sona ermesinin (infisahının) kaldırılmas1 anlamına gelir ${ }^{158}$. Diğer bir ifadeyle, tasfiye sürecine girmesi gereken ortaklık ilişkisi tekrar canlandırılmış ve sona ermekten kurtarılmış olmaktadır. Ortaklık ilişkisinin devamının tespiti bakımından, ortağın ölümünün üzerinden uzunca bir zaman geçmesine rağmen tasfiyeye gidilmeyerek ortaklığın sürdürülmesi önem arz etmektedir. Zira bu durum, ortaklığın sürüdürülmesine dair iradenin varlığına delil teşkil eder. Ancak ortaklık ilişkisinin devamı yönündeki iradenin tespiti için, ortağın ölümünün üzerinden uzunca bir zaman geçmesi zorunlu değildir ${ }^{159}$. Kanaatimizce burada hayatın olağan akışı çerçevesinde, ortağın ölümüne rağmen ortaklığın işlerinin mirasçılarla uygun bir süre devam edip etmediğine bakmak gerekmektedir. Sağ kalan ortaklarla mirasçılar arasında açık irade beyanlarının var olduğu durumlarda ise böyle bir kıstasa başvurmaya gerek kalmayacaktır.

\section{E. Ortaklık Sözleşmesindeki Devam Kayıtları ile Ölen Ortağın Ölüme Bağlı Tasarruf Özgürlüğü Arasındaki İlişki}

İsviçre öğretisinde ileri sürülen bir görüş, ortaklık sözleşmesinde devam kayıtlarının kararlaştırıldığı hallerde bile, ölen ortağın ölüme bağlı tasarruf yoluyla kendi ortaklık statüsü hakkında serbestçe tasarruf edebileceği kanaatindedir ${ }^{160}$. Bu görüşe göre, mirasbırakan ortak diğer ortakların rızaları gerekmeksizin ortaklık statüsünü ölüme bağlı tasarruf yoluyla belirli bir

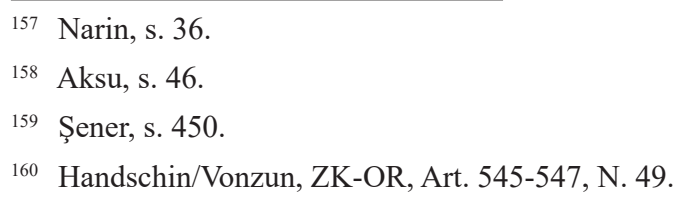


veya birden fazla mirasçısına devredebilir. Mirasbırakanın ölüme bağlı tasarrufta bulunma özgürlüğ̈̈, ortaklıklar hukukunda yer alan devam kayıtları ile sınırlandırılamaz ${ }^{161}$. Bu sebeple, mirasbırakan ortak, sözleşmede yer alan devam kaydına tamamen aykırı surette ölüme bağlı tasarruf yapabilir. Örneğin nitelikli devam kaydında adı geçen mirasçıların ortaklık payını değil, terekedeki başka bir malvarlığı değerini alacaklarını kararlaştırabilir. Dolayısıyla adi ortaklık, sanki mirasçılarla devam kaydı hiç kararlaştırılmamış gibi sona erecektir ${ }^{162}$.

Kanaatimizce İsviçre öğretisinde yer alan bu görüş, muhtelif yönlerden sakıncalıdır. Her şeyden evvel, mirasbırakanın ortaklık sıfatı kural olarak ölüme bağlı tasarrufa konu edilebilecek bir unsur değildir. Zira ortaklık sıfatı, ortağın kişiliğine sık1 sıkıya bağlıdır. Bu sebeple, ölen ortağın bir ölüme bağlı tasarrufla diğer ortakları göz ardı ederek kendi ortaklık sıfatı hakkında belirleme yapması mümkün değildir. Başka bir ifadeyle, mirasbırakan ölüme bağlı tasarrufu ile ortaklık sıfatının ölümünden sonra mirasçılarından birine ait olacağını belirtmiş olsa bile, bu durum söz konusu mirasçının kendiliğinden ortak sıfatını kazanması sonucunu doğurmayacaktır. TBK m. 639 hükmünün açı ifadesi çerçevesinde, ölen ortağın mirasçılarının ortaklığa dâhil olmalarının yolu, bütün ortakların muvafakatiyle ortaklık sözleşmesine bu yönde bir hükmün konulmasıdır. Nasıl ki bir ortağın tek taraflı olarak ortaklık payını üçüncü bir kişiye devretmesi bu üçüncü kişiye ortak sıfatını kazandırmıyorsa (TBK m. 632), ortaklardan birinin ortaklık sıfatını ölüme bağlı tasarrufla mirasçılarına bırakması da söz konusu mirasçılara ortaklık sıfatı kazandırmayacaktır. Bir ihtimal, diğer ortakların da taraf olacakları miras sözleşmesi ile bu sonucun ortaya çıkması mümkün olabilir.

Ölen ortağın, tasfiye payı ya da ayrılma payı için ölüme bağlı tasarrufta bulunmasının önünde ise bir engel yoktur. Zira söz konusu unsurlar, terekenin aktifinde bulunarak mirasçılara intikal edecektir. Mirasbırakan özellikle vasiyet (Vermächtnis) yoluyla tasfiye payı alacağının mirasçılarından birine verilmesini öngörebilir. Bunun dışında, ölüme bağlı tasarrufta bir paylaştırma kuralı (Teilungsvorschrift) şeklinde de tasfiye veya ayrılma payı alacağının kime ait olacağı düzenlenebilir. Ancak mirasçılar oybirliğiyle yapacakları bir anlaşma ile mirasbırakanın paylaştırma kuralını bertaraf edebilirler.

\footnotetext{
161 Handschin/Vonzun, ZK-OR, Art. 545-547, N. 49.

162 Handschin/Vonzun, ZK-OR, Art. 545-547, N. 49.
} 


\section{MİRASÇILARIN ADİ ORTAKLIKLA İLIŞKKILERININ MIRASIN PAYLAŞILMASINA ETKISII}

\section{A. Genel Olarak}

Mirasın paylaşı1ması ile adi ortaklık ilişkisi arasında ilk bakışta doğrudan bir bağlantı görülmez. Ancak ortaklık sözleşmesindeki devam kayıtları ya da mirasçıların ortaklığa devam edip etmemeye dair iradeleri, mirasın paylaşılmasına etki edebilecek hallerdir.

Ortağın ölümüyle birlikte ortaklığın tasfiye sürecine girdiği durumlarda, ölen ortağın mirasçılarının tasfiyeyi ve neticede ortaya çıkacak tasfiye payı alacağını talep etme hakları bulunmaktadır. Tasfiye payı alacağı, terekenin aktifinde yer alan bir unsur olarak paylaşma konusu olabilecek haklar grubunda yer almaktadır. Söz konusu alacağın gerek paylaşma davasına gerekse de mirasçıların kendi aralarında yapacakları paylaşma sözleşmesine konu edilmesi mümkündür.

Adi ortaklık sözleşmesinde sağ kalan ortaklarla devam kaydının bulunduğu ya da ortağın ölümünden sonra yapılan sözleşme ile bu durumun ortaya çıtığı hallerde de benzer bir sonuç ortaya çıkmaktadır. Ancak burada tasfiyeden farklı olarak, ölen ortağın ayrılma payının hesaplanarak mirasçılarına ödenmesi söz konusudur. Mirasçılar ayrılma payı alacağı hakkında paylaşma davası açabilecekleri gibi, bu alacağı konu edinen bir paylaşma sözleşmesi de yapabilirler.

Mirasçılarla devam kaydı bulunan hallerde ise kural olarak tasfiye ya da ayrılma payı gündeme gelmez. Zira bu durumda mirasçılar, miras ortaklığ olarak adi ortaklığa dâhil olmaktadırlar. Ortağın ölümü, ortaklığ 1 kendiliğinden sona erdiren bir hal olmaktan çıkmıştır. Dolayısıyla, mirasçıların tasfiye isteme hakları bulunmamaktadır. Hal böyle olmakla birlikte, mirasçıların adi ortaklıkta kalmaya zorlanmaları düşünülemez. Mirasçılardan biri, birkaçı veya tamamı ortaklıktan çıkmak isteyebilir. Böyle bir ihtimalde, çıkmak isteyen mirasçılara ayrılma paylarının ödenmesi gerekecektir. Aynı durum, ortaklığın bazı mirasçılarla devam edeceğine dair kayıtlarda da karşımıza çıkmaktadır. Ortaklık sözleşmesindeki kayıt sebebiyle ortaklık dışında kalan mirasçılara, kendi miras payları oranında ayrılma payı ödenmelidir.

\section{B. Tasfiye Payının veya Ayrılma Payının Paylaşma Sözleşmesine Konu Edilmesi}

Mirasçılar terekede bulunan mal veya hakların kime ait olacağı konusunda kendi aralarında bir paylaşma sözleşmesi yapabilirler (TMK m. 
676, ZGB Art. 634). Şu halde, terekede tasfiye payı alacağı ya da ayrılma pay1 alacağı bulunan hallerde, söz konusu alacaklar hakkında paylaşma sözleşmesi yapılması mümkündür.

Tasfiye payı ya da ayrılma payının tespit edildikten sonra paylaşma sözleşmesine konu edilmesi herhangi bir sorun teşkil etmez. Ancak bu tür bir paylaşma sözleşmesinin geçerli olması için adi yazılı şekilde yapılması gerekmektedir. Zira katılma payı veya ayrılma payı alacaklarının mirasçılardan birine tahsis edilmesi, esasen alacağın devrinden başka bir şey değildir ${ }^{163}$. Alacağın devrinin geçerliliği ise, yazılı şekilde yapılmış olmasına bağlıdır (TBK m. 184/1). Şu halde, mirasçılar terekede bulunan tasfiye payı ya da katılma payı alacaklarının içlerinden birine ait olmasını istiyorlarsa, adi yazılı bir paylaşma sözleșmesiyle bunu gerçekleștirebilirler. Paylaşma sözleşmesinde bütün mirasçıların veya yetkili temsilcilerinin imzalarının bulunmas1 gerekmektedir ${ }^{164}$. Bu şekilde paylaşma sözleşmesi tamamlandığ 1 takdirde, terekede bulunan tasfiye payı veya ayrılma payı alacağı, sözleşme ile devredilen mirasçıya geçer. Alacağın ilgili mirasçıya geçmesi için başkaca bir işleme gerek yoktur. Zira alacağın devri, hukuki niteliği itibariyle bir tasarruf işlemidir (Verfügungsgeschäft) ${ }^{165}$. Paylaşma sözleşmesi ile alacağ1 devralan mirasçı, söz konusu alacağın tahsili için gereken işlemleri tek başına yapabilecektir.

Mirasçıların henüz tasfiye payı ya da ayrılma payı tespit edilmeden de paylaşma sözleşmesi yapmaları mümkündür. Ancak böyle bir ihtimalde, mirasçıların muhtemel tasfiye payı ya da ayrılma payı alacağını sözleşmeye konu edip edemeyecekleri tereddüt oluşturabilir. Zira bu aşamada ortaya

163 Çabri, s. 504.

164 Ahmet M. Kılıçoğlu, Miras Taksim Sözleşmesi, 1. Bası, Yetkin Yayınları, Ankara, 1989, s. 76; Hayrunnisa Özdemir, Türk Medeni Kanununa Göre Mirasın Paylaşılması Şerhi, 1. Bas1, Yetkim Yayınları, Ankara, 2019, s. 212; Bilge Öztan, Miras Hukuku, 11. Bas1, Yetkin Yayınlar1, Ankara, 2020, s. 458.

165 Fikret Eren, Borçlar Hukuku Genel Hükümler, 25. Bask1, Yetkin Yayınları, Ankara, 2020, s. 1374; Kemal Oğuzman/Turgut Öz, Borçlar Hukuku Genel Hükümler C. II, 15. Bas1, Vedat Kitapçılık, İstanbul, 2020, s. 565; Hüseyin Hatemi/Emre Gökyayla, Borçlar Hukuku Genel Bölüm, 3. Bası, Vedat Kitapçılık, İstanbul, 2015, s. 377; Ahmet M. Kılıçoğlu, Borçlar Hukuku Genel Hükümler, 20. Bas1, Turhan Kitabevi, Ankara, 2016, s. 820; Andreas Von Tuhr/Arnold Escher, Allgemeiner Teil des Schweizerischen Obligationenrechts, Band II, 3. Auflage, Schulthess Verlag, 1974, s. 330; Peter Gauch/Walter Schluep/Jörg Schmid/Heinz Rey/Susan Emmenegger, Schweizerisches Obligationenrecht Allgemeiner Teil, Band II, Schulthess Verlag, Zürich, 2008, N. 3408; Hugo Oser/Wilhelm Schönenberger, Kommentar zum Schweizerischen Zivilgesetzbuch, Das Obligationenrecht, 2. Auflage, Schulthess Verlag, Zürich, 1936, Art. 165, N. 11. 
aktif bir malvarlığı değerinin çıkıp çıkmayacağı ya da bunun miktarı belirli değildir. Diğer bir ifadeyle, tasfiye ya da ayrılma paylarının hesabı neticesinde ortaya bir alacak çıkmayabilir. Kanaatimizce, bu durumda tasfiye payı veya ayrılma payı alacaklarının paylaşma sözleşmesine konu edilmesi geçerlidir. Henüz alacak belirli olmasa bile, paylaşma sözleşmesiyle müstakbel bir alacak mirasçılardan birine devredilmiş olacaktır. Alacağın devrinde müstakbel alacakların ve hatta devrin yapıldığı sırada henüz mevcut olmayan alacakların devredilmesi mümkündür ${ }^{166}$. Öyleyse, henüz tespit edilmeyen tasfiye veya ayrılma payı alacakları da devredilebilecektir. Bununla birlikte, TMK m. 679/2 hükmüne göre paylaşma sözleşmesi gereğince bir alacağı devralan mirasçıya karşı diğer mirasçılar, söz konusu alacağın varlığını garanti etmiş olurlar ${ }^{167}$. Kanun koyucu burada, alacağı devredenin garanti sorumluluğunu düzenleyen TBK m. 191/2 hükmünden bir yönüyle ayrılmıştır. Bahsedilen hükme göre, alacak bir edim karşılığı olmaksızın devredildiği takdirde, devreden alacağın varlığından ve borçlunun ödeme gücünden sorumlu değildir. Hâlbuki mirasın paylaşılması bakımından böyle bir ayrıma gidilmeksizin mirasçıların sorumlu olduğu ifade edilmiştir. Şu halde, sözleşme gereğince tasfiye payını ya da ayrılma payını devralan mirasçı, tasfiye sonucunda bu alacağı elde edemediği takdirde diğer mirasçılardan zararının giderilmesini talep edebilecektir.

Tasfiye payı ya da ayrılma payı mahkeme tarafindan belirlendiği takdirde, ölen ortağın payı için mirasçılara ödenen meblağ, onlar arasında sözleşme ile paylaşılabilir. Böyle bir ihtimalde paylaşma sözleşmesinin adi yazılı olma zorunluluğu da yoktur. Terekede bulunan bir miktar para, yazılı paylaşma sözleşmesi olmaksızın elden paylaşılabilir.

\section{Tasfiye Payının veya Ayrılma Payının Paylaşma Davasına Konu Edilmesi}

Mirasçılar arasında anlaşma mümkün olmadığı takdirde, ölen ortağın tasfiye payı veya ayrılma payı bakımından paylaşma davası açılması gündeme gelecektir. Tasfiyenin tamamlandığı veya ayrılma payının ödendiği hallerde paylaşma davasının açılması bakımından bir tereddüt söz konusu değildir. $\mathrm{Bu}$ durumda mahkeme, terekede bulunan diğer mal veya haklar gibi, tasfiye payı veya ayrılma payını da tereke mevcuduna dâhil eder. Hatta yalnızca

166 Eren, Genel Hükümler, s. 1375; Von Tuhr/Escher, s. 349; Gauch/Schluep/Schmid/Rey/ Emmenegger, N. 3421; Oser/Schönenberger, Art. 164, N. 4. Aksi görüşte: Oğuzman/Öz, C. II, s. 554-555.

167 K1lıçoğlu, Taksim, s. 119; Öztan, s. 501; İmre/Erman, s. 576; Antalya/Sağlam, s. 534; Serozan/Engin, s. 610; İnan/Ertaş/Albaş, s. 609; Çabri, s. 570. 
terekedeki tasfiye payı veya ayrılma payının paylaşılması için dava açılması da mümkündür ${ }^{168}$. Burada asıl tereddüt oluşturan husus, mirasçıların henüz tasfiye işlemlerine başlanmadan ya da ayrılma payı hesaplanmadan bunların paylaşılması için dava açıp açamayacaklarıdır. Kanaatimizce bu aşamada paylaşma davası açılsa bile, davanın görüldüğü mahkeme tasfiye işlemlerinin tamamlanmasını bekletici mesele yapmak durumundadır. Zira terekenin net malvarlığı, ortaklığın tasfiyesi veya ölen ortağın ayrılma payının belirlenmesi neticesinde ortaya çikacaktır.

Mirasçıların ortaklığın tasfiyesi ya da ayrılma payının belirlenmesi talebiyle birlikte, belirlenen meblağın paylaştırılmasını da isteyip isteyemeyecekleri sorusu akla gelebilir. Böyle bir talep usul ekonomisi ilkesi bakımından uygun gibi görünse de, yine usul hukuku çerçevesinde mümkün değildir. Zira adi ortaklığın tasfiyesine ilişkin davalarda asliye hukuk mahkemesi görevlidir ${ }^{169}$. Ölen ortağın ayrılma payının tespiti için açılacak dava bakımından da aynı husus geçerlidir. Terekede bulunan mal veya hakkın paylaştırılması için açılacak davalarda ise sulh hukuk mahkemesi görevlidir (HMK m. 4/1-b). Öte yandan söz konusu davaların tarafları da birbirinden farklıdır. Dolayısıyla, tasfiye payının veya ayrılma payının tespiti için dava açıldıktan sonra, ayrıca bunun paylaştırılması için dava açmak gerekecektir.

\section{SONUÇ}

Kişi ortaklıklarının bir türü olan adi ortaklık, kural olarak ortaklardan birinin ölümü anında kendiliğinden sona erer. Ancak ortaklığın sona ermesi, ortaklık ilişkisinin birdenbire yok olması anlamına gelmez. Ortaklığın amacı tasfiye amacına dönüşür ve süreç tamamlanana kadar bu amaçla sınırlı olarak varlığını devam ettirir. Ölen ortağın mirasçıları, miras ortaklığı halinde tasfiye ortaklığına girerler. Tasfiye sonucunda elde edilen kazanç ortaklar arasında dağıtılır ve ölen ortağın payına düşen kısım da onun terekesinin bir parçası olarak mirasçılarına intikal eder. Benzer bir durum, ortaklığın zarar etmesi halinde de karşımıza çıkar. Diğer bir deyişle, ortaklığın zararından ölen

168 Terekede bulunan bazı mallar için paylaşma davası açılıp açılamayacağı hakkında bkz: Mehmet Serkan Ergüne, "Terekedeki Münferit Mallar İçin Kısmi Paylaşma Davası Açma İmkânının Değerlendirilmesi”, Marmara Üniversitesi Hukuk Fakültesi Hukuk Araştırmaları Dergisi, C. 22, S. 3, Prof. Dr. Cevdet Yavuz'a Armağan, s. 1063 vd.

169 "Adi ortaklık sözleşmesi; iki ya da daha fazla kişinin emeklerini ve mallarını ortak bir amaca erişmek üzere birleştirmeyi üstlendikleri sözleşmeler olup, (TBK. 620/1 md.) bu sözleşme türü Borçlar Kanunu'nda düzenlenmiştir. Bu nedenle, adi ortaklı̆̆ın feshi ve tasfiyesine ilişkin davalara bakma görevi de genel mahkeme olan asliye hukuk mahkemelerine aittir". Yarg. 3. HD, E. 2016/3445, K. 2017/14215, T. 19.10.2017. 
ortağın payına düşen kısım terekenin pasifinde yer alır.

Ortaklardan birinin ölmesiyle birlikte ortaklığın tasfiyeye girmesi, bazı durumlarda istenmeyen bir sonuç olabilir. Özellikle uzun süreli olarak faaliyet göstermek üzere kurulmuş olan ortaklıklarda, ortağın ölümünün bu durumu akamete uğratması arzu edilmez. Öyleyse, ortaklardan birinin ölümünün adi ortaklığı sona erdiren bir sebep olmaktan çıkarılması gerekmektedir. Bunun için de ortaklık sözleşmesinde veya ayrı bir sözleşmede, ortaklardan birinin ölümünden sonra da ortaklığın devam edeceğinin kararlaştırılması gerekmektedir. Kısaca "devam kaydı" olarak ifade edilen bu kayıt, içerik olarak farklı şekillerde tasarlanabilir. Ölen ortağın bütün mirasçıları ile veya sadece bir ya da birkaç mirasçısı ile adi ortaklığın sürdürülmesi öngörülebilir. Bunun dışında, mirasçıların aradan çıkarılarak ortaklığın yalnızca sağ kalan ortaklarla devam etmesi de bir başka seçenektir. Bunlarla beraber, ölen ortağın mirasçılarına ortaklığa girip girmeme konusunda bir seçim hakkı tanınması da mümkündür. Bahsedilen bu ihtimallerden en sorunsuz olan1, ortaklığın sağ kalan ortaklarla devamına karar verilmesidir. Zira bu ihtimalde, mirasçıların bir bütün olarak miras ortaklığı halinde adi ortaklığa girmelerinin yaratacağ1 bir dizi sorunun önüne geçilmiş olunacaktır. Ancak bu seçeneğin uygulanması tamamen sakıncasız da değildir. Sözleşmedeki kayıt gereğince adi ortaklık dışında kalan mirasçılara ölen ortağın ayrılma payının ödenmesi gerekecektir. Ortaklığın mali bakımdan iyi durumda olmaması halinde söz konusu ayrılma payını ifa borcu, ortaklığın devamının zorlaşmasına ve neticede feshedilmesine sebep olabilir.

Ortakların ölümden sonra ortaklığın akıbeti hakkında sözleşmeye bir kayıt koymamaları halinde, kural olarak ortaklığın tasfiye edilmesi gerekecektir. Fakat yine de ortaklığın devamını sağlamak için sağ kalan ortaklarla mirasçıların anlaşmaya varmaları mümkündür. Bu noktada özellikle ortaklığın işlerinin mirasçılar ve sağ kalan ortaklar tarafından devam ettirilmesi önem taşımaktadır. Zira böyle bir durum, ortaklığın devamına yönelik örtülü de olsa bir sözleşmenin varlığına delil teşkil edebilir. 


\section{KAYNAKÇA}

Aksu S, Adi Ortaklığın Sona Erme Sebepleri, Yayınlanmamış Yüksek Lisans Tezi, Dokuz Eylül Üniversitesi Sosyal Bilimler Enstitüsü, İzmir, 2011.

Antalya O.G/Sağlam İ, Miras Hukuku, 4. Bası, Seçkin Yayınları, Ankara, 2019.

Ayar A, Adi Ortaklıkta İç ve Dış İlişkiler, 1. Baskı, İstanbul, 2019.

Aykun M.A, Adi Ortaklığın Sona Ermesi ve Tasfiyesi, Yayınlanmamış Yüksek Lisans Tezi, Erciyes Üniversitesi Sosyal Bilimler Enstitüsü, Kayseri, 2019.

Barlas N, Adi Ortaklık Temeline Dayalı Sözleşme İlişkileri, 4. Bası, Vedat Kitapç1lı, İstanbul, 2016.

Bornhauser P.R, "Gesamteigentum und einfache Gesellschaft: Vorrang sachenrechtlicher Bestimmungen bei der Liquidation", Aktuelle Juristische Praxis, 2014, Dike Verlag AG, ss. 649-653.

Casutt A, OFK - Orell Füssli Kommentar, Schweizerisches Obligationenrecht, 3. Auflage, Orell Füssli Verlag AG, 2016.

Christ B.F, SHK - Stämpflis Handkommentar, Personengesellschaftsrecht (Art. 530-619 OR), Stämpfli Verlag AG, 2015.

Çabri S, Miras Hukuku Şerhi, Cilt-III, 1. Baskı, Oniki Levha Yayınları, İstanbul, 2020.

Domaniç H, Türk Ticaret Kanunu Şerhi, Cilt I, İstanbul, 1988.

Eren F, Borçlar Hukuku Genel Hükümler, 25. Bask1, Yetkin Yayınları, Ankara, 2020.

Eren F, Borçlar Hukuku Özel Hükümler, 5. Bası, Yetkin Yayınları, Ankara, 2017.

Ergüne M.S, “Terekedeki Münferit Mallar İçin Kısmi Paylaşma Davası Açma İmkânının Değerlendirilmesi”, Marmara Üniversitesi Hukuk Fakültesi Hukuk Araştırmaları Dergisi, C. 22, S. 3, Prof. Dr. Cevdet Yavuz'a Armağan, ss. 1063-1085.

Fellmann W/Müller K, BK - Berner Kommentar Band/Nr. VI/2/8, Schweizerisches Zivilgesetzbuch, Das Obligationenrecht, Die einzelnen Vertragsverhältnisse, Stämpfli Verlag AG, 2006. 
Gauch P/Schluep W/Schmid J/Rey H/Emmenegger S, Schweizerisches Obligationenrecht Allgemeiner Teil, Band II, Schulthess Verlag, Zürich, 2008.

Girgin Ö.A, Adi Ortaklıkta Temsil ve Borçlardan Sorumluluk, 1. Bask1, İstanbul, 2017.

Handschin L, "Die Auflösung der einfachen Gesellschaft", Gesellschafts- und Kapitalmarktrecht in Deutschland, Österreich und der Schweiz, Mohr Siebeck, Tübingen, 2014, ss. 215-254.

Handschin L/Chou H.L, ZK - Zürcher Kommentar, Kommentar zum schweizerischen Zivilrecht, Die Kollektivgesellschaft, Die Kommanditgesellschaft, Art. 552-619 OR, 4. Auflage, Schulthess Juristische Medien AG, 2009.

Handschin L/Vonzun R, ZK - Zürcher Kommentar Band/Nr. V/4a, Kommentar zum schweizerischen Zivilrecht, Obligationenrecht, 4. Teil: Die Personengesellschaften, 4. Auflage, Schulthess Juristische Medien AG, 2009.

Hatemi H/Gökyayla E, Borçlar Hukuku Genel Bölüm, 3. Bas1, Vedat Kitapç1lık, İstanbul, 2015.

Herren D, SHK - Stämpflis Handkommentar, Personengesellschaftsrecht (Art. 530-619 OR), Stämpfli Verlag AG, 2015.

İmre Z/Erman H, Miras Hukuku, 13. Bası, Der Yayınları, İstanbul, 2017.

İnan A.N/Ertaş Ş/Albaş H, Miras Hukuku, 10. Bası, Seçkin Yayınları, Ankara, 2019.

Jörg F.S, SHK - Stämpflis Handkommentar, Personengesellschaftsrecht (Art. 530-619 OR), Stämpfli Verlag AG, 2015.

Jung P, "Die Regelung der Nachfolge beim Tod eines PersonengesellschaftersZum notwendigen Zusammenspiel von Erbrecht und Gesellschaftsrecht", Entwicklungen im Gesellschaftsrecht XII, Stämpfli Verlag AG, 2017, ss. 172-217.

Jung P, CHK - Handkommentar zum Schweizer Privatrecht, Personengesellschaften und Aktiengesellschaft -Vergütungsverordnung, 3. Auflage, Schulthess Juristische Medien AG, 2016.

Karayalçın Y, Ticaret Hukuku II, Şirketler Hukuku, 2. Bası, Ankara, 1973. 
Kılıçoğlu A.M, Borçlar Hukuku Genel Hükümler, 20. Bası, Turhan Kitabevi, Ankara, 2016.

Kılıçoğlu A.M, Miras Taksim Sözleşmesi, 1. Bası, Yetkin Yayınları, Ankara, 1989.

Krauskopf F/ Girón S, SHK - Stämpflis Handkommentar, Personengesellschaftsrecht (Art. 530-619 OR), Stämpfli Verlag AG, 2015.

Maraşlı Dinç Y, Miras Hukukunda Külli Halefiyet İlkesi, Yayınlanmamış Yüksek Lisans Tezi, Ankara Hac1 Bayram Veli Üniversitesi Lisansüstü Eğitim Enstitüsü, Ankara, 2020.

Müller K, OFK - Orell Füssli Kommentar, Schweizerisches Obligationenrecht, 3. Auflage, Orell Füssli Verlag AG, 2016

Narin R, Adi Şirketin Sona Ermesi, Yayınlanmamış Yüksek Lisans Tezi, Ankara Üniversitesi Sosyal Bilimler Enstitüsü, 2010.

Oğuzman K/Öz T, Borçlar Hukuku Genel Hükümler C. II, 15. Bası, Vedat Kitapç1lı, İstanbul, 2020.

Oser H/Schönenberger W, Kommentar zum Schweizerischen Zivilgesetzbuch, Das Obligationenrecht, 2. Auflage, Schulthess Verlag, Zürich, 1936.

Özdemir H, Türk Medeni Kanununa Göre Mirasın Paylaşılması Şerhi, 1. Bası, Yetkim Yayınları, Ankara, 2019.

Özenli S, Uygulamada Adi Ortaklık ve Neden Olduğu Davalar, 1. Bası, Ankara, 1988.

Öztan B, Miras Hukuku, 11. Bası, Yetkin Yayınları, Ankara, 2020.

Peksöz V, Medeni Usul Hukuku Açısından Adi Ortaklık İlişkileri, 1. Baskı, İstanbul, 2020.

Poroy R/Tekinalp Ü/Çamoğlu E, Ortaklıklar ve Kooperatif Hukuku, Vedat Kitapçılık, İstanbul, 2010.

Schütz J.G, SHK - Stämpflis Handkommentar, Personengesellschaftsrecht (Art. 530-619 OR), Stämpfli Verlag AG, 2015.

Serozan R, Sağlararası İşlem Yoluyla Ölüme Bağlı Kazandırma, 1. Bası, İstanbul, 1979.

Serozan R/Engin B.İ, Miras Hukuku, 6. Bası, Seçkin Yayınları, Ankara, 2019. 
Steininger T.A, SHK - Stämpflis Handkommentar, Personengesellschaftsrecht (Art. 530-619 OR), Stämpfli Verlag AG, 2015.

Strittmatter R, CHK - Handkommentar zum Schweizer Privatrecht, Personengesellschaften und Aktiengesellschaft - Vergütungsverordnung, 3. Auflage, Schulthess Juristische Medien AG, 2016.

Şener O.H, Adi Ortaklık, 1. Baskı, Yetkin Yayınları, Ankara, 2008.

Thouvenin F, Der Kooperationsvertrag, Kooperationen im Grenzbereich von Vertrags- und Gesellschaftsrecht, Stämpfli Verlag AG, 2017.

Truniger C, Präjudizienbuch OR, 9. Auflage, Schulthess Juristische Medien AG, 2016.

Türkmen E, Adi Ortaklıkta Çıkma ve Çıkarılma, 1. Baskı, Seçkin Yayınları, Ankara, 2020.

Ulmer P/Schäfer C, Münchener Kommentar zum Bürgerlichen Gesetzbuch, 8 . Auflage, C.H.Beck Verlag, 2021.

Ulusoy E, “Adi Ortaklığın Tasfiyesi ve Mahkemelerin Görevi”, Uyuşmazlık Mahkemesi Dergisi, C. 5, S. I, 2015, ss. 879-904.

Ünal A, Kelepçeleme Sözleşmeleri, 2. Baskı, Adalet Yayınevi, Ankara, 2017.

Von Tuhr A/Escher A, Allgemeiner Teil des Schweizerischen Obligationenrechts, Band II, 3. Auflage, Schulthess Verlag, 1974.

Vonzun R, "Die einfache Gesellschaft im Zivilprozess - ausgewählte Fragen", Theorie und Praxis des Unternehmensrechts Festschrift zu Ehren von Lukas Handschin, Schulthess Juristische Medien AG, 2020, ss. 751-765.

Wolf S, "Erb- und (immobiliar)sachenrechtliche Aspekte der einfachen Gesellschaft, insbesondere im Zusammenhang mit personellen Wechseln im Bestand der Gesellschafter", Güter- und erbrechtliche Fragen zur einfachen Gesellschaft und zum bäuerlichen Bodenrecht, Stämpfli Verlag AG, 2005, ss. 47-97.

Yavuz C/Acar F/Özen B, Türk Borçlar Hukuku Özel Hükümler, Beta, 10. Bas1, İstanbul, 2014.

Yıldırım A.H, "Adi Ortaklıkta Ortakların Denetleme Hakk1 (TBK 631)", Dokuz Eylül Üniversitesi Hukuk Fakültesi Dergisi, C. 13, S. 2, 2011, ss. 195-216. 